\title{
Wood anatomy of Late Triassic trees in Petrified Forest National Park, Arizona, USA, in relation to Araucarioxylon arizonicum Knowlton, 1889
}

\author{
RODNEY ARTHUR SAVIDGE
}

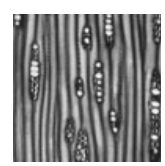

\begin{abstract}
Thin sections from the three syntypes of Araucarioxylon arizonicum Knowlton, 1889 were re-examined and found to be anatomically distinct. Two of the syntypes are similar and, considering Araucarioxylon ("Araucaroxylon") Kraus, 1870 as nomen superfluum, those two are placed in Pullisilvaxylon gen. $\mathrm{n}$. as nomen novum (lectotype Pullisilvaxylon arizonicum). The third specimen, known as the 'Sherman log', is transferred to Chinleoxylon knowltonii gen. et sp. n. Permineralized woods in three randomly sampled large-diameter logs assumed to be A. arizonicum plesiotypes were found to be anatomically distinct, two being species within Silicisilvaxylon gen. n., the third named Crystalloxylon imprimacrystallum gen. et sp. n. Thus, following descriptions of Arboramosa semicircumtrachea Savidge \& Ash, 2006, Protocupressinoxylon arizonicum Savidge, 2006, and Ginkgoxylpropinquus hewardii Savidge, 2006, this study further increases the region's number of woody plant morphotaxa and indicates that a diversity of large conifer species were co-evolving with cycads and ginkgo-like trees during Late Triassic. $\bullet$ Key words: Triassic, Pinophyta, Araucaria-type wood, North America, oculipore, Protopiceoxylon novum, ray, resin canal, resinous tracheid, secondary xylem, tracheidoxyl, new taxa.
\end{abstract}

SAVIDGE, R.A. 2007. Wood anatomy of Late Triassic trees in Petrified Forest National Park, Arizona, USA, in relation to Araucarioxylon arizonicum Knowlton, 1889. Bulletin of Geosciences 82(4), 301-328 (7 figures, 2 tables). Czech Geological Survey, Prague. ISSN 1214-1119. Manuscript received April 5, 2007; accepted in revised form July 16, 2007; issued December 31, 2007. • DOI 10.3140/bull.geosci.2007.04.301

Rodney Arthur Savidge, Forestry \& Environmental Management, University of New Brunswick, Fredericton, NB, CanadaE3B6C2; savi@unb.ca

The presumption that Araucarioxylon arizonicum Knowlton, 1889 was the dominant and persistent conifer during Late Triassic in what is now southwestern USA arose following the original descriptions of Araucaroxylon (sic "Araucarioxylon") as a new genus (Kraus 1870), Araucarioxylon arizonicum as a new species (Knowlton 1889, 1890 ), and subsequent work on petrified logs in the region by Knowlton $(1913,1919)$ and Daugherty (1941). Investigating petrified logs found within the area later designated as Petrified Forest National Park (PEFO) as well as in the surrounding region, Daugherty (1941) concluded that "judging from the thousands of logs in the fossil record, this form constitutes the dominant species in this widespread Triassic forest". After examining petrified wood from an unspecified number of localities in the Upper Triassic of the southwest, Scott (1961) also indicated that most if not all logs belonged to Araucarioxylon arizonicum.

Putative A. arizonicum logs of southwestern USA are generally long and of large diameter and, superficially, they display more or less similar bole surfaces with non-whorled branch scars (Knowlton 1913, Ash 1992, Ash
\& Creber 2000). The distribution of those petrified $\operatorname{logs}$ among the generally horizontal strata of the Late Triassic Chinle Formation is non-uniform, rather concentrated to its lowermost Shinarump Member (conspicuous in southeastern Utah) and in the overlying Sonsela Member (exposed in the southern half of PEFO) within the southern half of the Colorado Plateau. Logs also occur above the Sonsela in the Wolverine Petrified Forest (southeastern Utah) and in the upper Chinle within the Black Forest Bed (localized to the northern part of PEFO). Although PEFO is undoubtedly the best location in southwestern USA to readily find exposed petrified logs within the Chinle, even there the logs are found as fairly discrete deposits separated by a number of lithological units representing many millions of years of deposition extending from Late Carnian into Norian (Riggs et al. 2003, Parker 2006, Woody 2006). Detailed studies aimed at substantiating the implicit assumption of persistently homologous wood anatomy among all the region's large diameter petrified logs across this time span have only begun (Savidge 2006, Savidge \& Ash 2006). 
Four new morphotaxa, viz., Arboramosa semicircumtrachea Savidge \& Ash, 2006, Protocupressinoxylon arizonica Savidge, 2006, Ginkgoxylpropinquus hewardii Savidge, 2006 and Protopiceoxylon novum Savidge, 2006, from the region of Petrified Forest National Park (PEFO) in Arizona, USA, were recently typified based on each specimen having a novel set of secondary xylem anatomical features. Although the four at the outset were presumed to be $A$. arizonicum plesiotypes, they were found to be anatomically diverse, emphasizing the need for unambiguous criteria to recognize and distinguish Araucarioxylon arizonicum wood unequivocally from other Mesozoic tracheidoxyls (i.e. permineralized fragments of pycnoxylic secondary xylem - Creber 1972).

In order to better define the Araucarioxylon arizonicum type, the original syntype thin sections prepared by Knowlton (1889) were re-examined and their anatomical details compared with those of other morphotaxa previously established to be present in the PEFO region, as well as with features displayed by additional three randomly selected PEFO logs initially assumed to be specimens of A. arizonicum. However, re-examination of the syntypes revealed both anatomical disparity and lack of concordance with the original Araucaroxylon Kraus, 1870 type diagnosis. Moreover, the three presumed plesiotypes were also found to be anatomically distinct (Table 1). Exacerbating the difficulties attending this anatomical heterogeneity, there has been a long-standing problem with Araucaroxylon (sic Araucarioxylon) nomenclature (see history section below). Seward (1917) rejected the genus Araucarioxylon and suggested that all araucarian fossil woods that could not be better placed should go into Dadoxylon. More recently, Philippe (1993) followed by Bamford \& Philippe (2001) gave reasons for considering both Araucarioxylon and Dadoxylon as nomina superflua, and they suggested many taxa assigned to those genera could be assigned to Agathoxylon Hartig, 1848. The Agathoxylon type is represented by $A$. cordaianum, a Late Triassic (Keuper) type from Austria having uniseriate rays, axial parenchyma, and contiguous and compressed or crowded cross-field pits (M. Philippe, personal communication). The latter requirement, for contiguous, compressed or at least crowded cross-field pits, if applied sensu stricto, will probably exclude most already known Araucarioxylon and Dadoxylon morphotaxa. Considering the uncertain affinities, the aim of the research presented here necessarily extended beyond trying to define anatomical criteria for distinguishing Late Triassic southwestern USA woods to developing new nomenclature to systematize earlier described morphotaxa and support ongoing enquiry into the many specimens remaining to be investigated.

\section{History of Araucarioxylon nomenclature preceding A. arizonicum Knowlton, 1889}

At the outset of anatomical investigations into petrified woods, Witham (1833) provided clear evidence for hexagonally angular, contacting, multi-seriate bordered pits in a fossil wood that he described as Pinites. Göppert (1850) decided that this wood should be renamed Araucarites, also that fossil woods anatomically similar to those within extant Pinaceae (which Witham 1833 had described as morphotypes of Pitus) were better referred to as Pinites. However, Endlicher (1847) had earlier instituted Dadoxylon to refer to such tracheidoxyls and argued that Araucarites should not be used to refer to wood of Araucaria-like fossils, rather only to leaves and reproductive structures. Therefore, use of Araucarites by Göppert (1850) was incorrect. Moreover, Hartig (1848) had already initiated the genus Agathoxylon (also known as Dammaroxylon) on the basis of the same, or very similar, tracheidoxyl features recognized by Göppert (1850) for his Araucarites.

Kraus (1870) initiated Araucaroxylon (sic) for woods presumed to be organically associated with leaves and reproductive structures of Araucarites. When Kraus (1870, pp. 380, 381) described "Araucaroxylon", he provided the following diagnosis: "Lignum stratis concentricis distinctis vel obsoletis; cellulis prosenchymatosis porosis; poris magnis rotundis, rarius uniserialibus contiguis, creberrime pluriserialibus spiraliter dispositis compressione mutua hexagonis; cellulis ductibusque resiniferis nullis; radiis medullaribus uni- rarius pluriseriatis" (literal English translation, with more esoteric interpretations in brackets: 'Wood with concentric divisions [growth interruptions, annual rings] present or absent; porous prosenchyma cells [tracheids]; large round pores [bordered pits] infrequently uniseriate and contiguous, frequently [or dominantly] multi-seriate, spirally arranged, compressed and hexagonal in shape; no resinous conducting cells [resinous tracheids]; medullary rays uniseriate rarely pluriseriate').

Within that diagnosis, Kraus (1870) wrote that "Araucarites Goepp., Dadoxylon Endl. Ung., Protopitys G., Pissadendron Endl. Goepp., Palaeoxylon Brongt." and also Pinites Witham, 1883 were to be incorporated into Araucaroxylon, and although Kraus (1870) provided no detailed diagnoses for any, he transferred 32 species in those genera to a type with a slightly different spelling, viz., "Araucarioxylon", nom. alt. The reason for the two spellings is unclear, but Kraus (1870) clearly agreed with the view of his time that Mesozoic and Palaeozoic woods could not be assigned to species and should only be considered in terms of broad taxonomic groups. That thinking may underlie the two spellings as well as his limited consideration of the many anatomical features he might otherwise have specified in order to more fully define the 
Araucaroxylon type and each of the 32 species reassigned to Araucarioxylon.

Following the proposal of Araucaroxylon by Kraus (1870), varied interpretations of anatomical features diagnostic of Araucarioxylon secondary xylem were published, predicated on the idea that Araucarioxylon wood anatomy should be 'araucarian' or similar to what is found in extant Araucaria species (Andrews 1970). Concepts that Araucarioxylon woods should display alternating bi-seriately ordered hexagonal bordered pits, abundant cross-field pits, and annual rings were advocated (e.g., Knowlton 1890; Seward 1904; Jeffrey 1910, 1911; Holden 1913; Stopes 1914; Daugherty 1941; Kräusel 1949; Andrews 1970), although Kraus (1870) had specified none of those. It can be argued that had Kraus (1870) wished to emphasize bi-seriate pitting, he would have written 'creberrime biserialibus' rather than "creberrime pluriserialibus" because citations in Kraus (1870) indicate that he must have been aware of contacting, hexagonally shaped multiseriate bordered pits in various Late Palaeozoic and Mesozoic tracheidoxyls. Kraus (1870) evidently wished to make multi-seriate, as opposed to bi-seriate, pitting a diagnostic requirement for Araucaroxylon woods. Kraus (1870) made no reference to cross-field pitting in Araucaroxylon, and he considered evidence for interruptions in cambial growth, or 'annual rings', to be of little or no taxonomic value. Parenthetically, repetitive well-delineated fully circumferential growth interruptions in fossil woods, such as are displayed in Protocupressinoxylon arizonica Savidge, 2006, may well be an indication of annual rings having been formed, hence of the occurrence of an annual cycle of growth and dormancy and the underlying existence in a species of cold-hardiness genes (Savidge \& Förster 1998). However, interpretation of indefinite, sporadic, widely distributed growth interruptions in wood as 'annual' rings indicative of cambial dormancy is difficult to justify. Those zones in wood more likely manifest a slowing or temporary interruption of cambial growth as a physiological response that all tree species appear capable of when the external environment becomes momentarily limiting, e.g., in response to drought, overly warm conditions, or reduced lighting (i.e. suppression - Savidge 1993).

A further complication emerged when a number of investigators after Kraus (1870) accepted the view that specimens in Permian or older strata having wood anatomy viewed as the Araucarioxylon type should be placed in Dadoxylon Endlicher, 1847, reserving Araucarioxylon for Mesozoic fossils (Morgenroth 1883, Knowlton 1890, Darrah 1939). But not everyone agreed; for example, Solms-Laubach \& Graf (1891) described Early Devonian specimens designated Dadoxylon Dawson, 1871 and Cordaites Unger, 1850 of the Carboniferous and Permian periods to be Palaeozoic ancestors, if not equivalents, to Araucarioxylon.
Gothan (1905) thought that the "medullary" rays in araucarian woods were to be of high frequency and long (30-50 cells high), normally uniseriate but occasionally bi-seriate, and to have one to two pits per cross-field. [Note: Secondary xylem rays tend to be distinct from medullary rays in size, cross-field pitting and other features, but Kraus (1870), Gothan (1905) and other researchers evidently were unaware of medullary-independent modes of ray initiation - Bannan \& Bayly 1956]. A consensus evidently developed that the number of bordered pits on radial walls of Araucarioxylon was to be much larger than that on the tangential walls (Gothan 1905, Conrad 1910, Pool 1929). Seward (1919, p. 143) considered tangential pits should be absent, but Pool (1929) was of the view that pits on tangential walls should be "fairly numerous".

Jeffrey (1911) wrote about Araucarioxylon Kraus, 1870: "As the result of recent investigations into the structure of mesozoic conifers, we now know that the wood genus does not cover all the araucarian ligneous types of the past. This genus is characterized by alternating or flattened pits on the radial walls of the tracheids, by smooth-walled ray cells, and incidentally by the absence of resin canals formed as a result of wounding... The enumeration of araucarian woods, however, is not exhaustive, for recently a new type has been described in which the alternating or flattened pitting, which on the former understanding of the Araucarineae was characteristic of the wood of this coniferous stock, is entirely absent. Thus we come to the paradox of an araucarian wood without araucarian pitting." Sinnott (1909) had already considered that Paracedroxylon was an araucarian wood when Jeffrey (1911) cited Gerry (1910) in stating that "the essence of the araucarian ligneous type is the absence of the bars of Sanio in the tracheids, and not necessarily the mode of arrangement or the shape of the radial pits of the tracheids". (In referring to bars of Sanio Jeffrey undoubtedly was actually referring to crassulae, earlier known as rims of Sanio, seen as horizontally oriented cell-wall modifications separating bordered pits).

In a further effort to define the Araucarioxylon type, Jeffrey (1913) considered that "the pits are numerous and in several rows, with the marked alternation, characteristic of the Araucarioxylon type." Interestingly, this reference to "numerous" bordered pits in "several rows" agreed with Kraus (1870) and diverged from the view of many previous investigators.

Much later, Andrews (1970) proposed that Araucarioxylon carbonaceum (Witham) Kraus, 1870 should be the type species for the genus, using the following diagnosis: "Bordered pits on radial walls of tracheids are most commonly uniseriate and more rarely arranged in two or more rows. Uniseriate pits are often separate and circular, but may also be flattened above and below. Where 
biseriate, pits are alternate and polygonal. One to 15 pits occur per cross-field, which may be simple, bordered, circular or elliptical in character. Rays uniseriate, more rarely double. Resin canals and axial parenchyma absent or rare. Annual rings distinct." Kraus (1870) had clearly stated that uniseriate pitting was to be infrequent, and the type proposed by Andrews (1970) therefore cannot be readily reconciled with the original Araucarioxylon Kraus, 1870 type description. Moreover, although inclusion of cross-field pitting was a useful addition, the wording "one to 15 pits... per cross-field" arguably provided excessive diagnostic latitude for morphotaxa, particularly as cross-field pitting can be one of the more diagnostic features for wood identification (Eckhold 1922, Phillips 1948, Philippe 1995, Panshin \& de Zeuuw 1980).

\section{History of Araucarioxylon arizonicum Knowlton, 1889}

The three syntypes of Araucarioxylon arizonicum are housed in the Smithsonian Institution, and the historical record indicates that they originated from at least two locations, the Black Forest Bed in Petrified Forest National Park (PEFO) and near Fort Wingate, New Mexico, approximately $125 \mathrm{~km}$ northeast of Lithodendron Wash in Petrified Forest National Park (Fig. 1). Hegewald (in Swaine \& Hegewald 1882) remarked: "I encountered considerable difficulty in trying to procure two specimens ... After finding the larger of the two fossils sent, I could find no mate, the remainder being of a different species, and the exposed part broken in segments too short to answer. Finally, I concluded to unearth part of the same specimen... This was on the right bank of Lithodendron, 1 1/4 miles from Bear Spring." The Lithodendron location although not precisely known generally agrees with the locale of the Black Forest Bed within Petrified Forest National Park (Parker 2006), and permineralized logs associated with the Black Forest Bed generally exhibit distinctively black wood (Ash 1992) similar to that displayed by two of the syntypes. Hegewald indicated that both sections came from the same log but, as explained below, based on the anatomical evidence it appears that he was mistaken. Moreover, P.T. Swaine (in Swaine \& Hegewald 1882) noted that "only one of the two specimens obtained from the Lithodendron by Lieutenant Hegewald was forwarded to Washington. This is the large dark-colored one. In the place of the second one brought in from the locality of the Lithodendron a better specimen was found on the mesa to the north of and adjacent to Fort Wingate, about 2 miles from the flag-staff. This is the smaller and lighter-colored one". Fort Wingate is approximately $125 \mathrm{~km}$ northeast of PEFO (Figure 1), and the smaller, lighter-colored one is assumed to be the 'Sherman log' otherwise designated as USNM 30862 (J.G. Wingerath, personal communication), because that log best fits the description given by P.T. Swaine.

Knowlton (1889) evidently had no role in collection or receipt of the three logs, and he began to type them several years after they arrived at the Smithsonian Institution. In view of the records provided by Hegewald \& Swaine (1882), Knowlton (1889) was confronted with the difficulty of having to explain the presence of three rather than two logs. He believed but was unable to confirm that the two dark logs in the U. S. National Museum had "probably came from Lithodendron, in Arizona" because they were both "black throughout". Following his investigations into those two and the third less dark log, Knowlton (1889, 1890) concluded that all three "belong to the genus Araucarioxylon, and probably are of the same species". However, Knowlton (1889, 1890) did not designate any particular log as the holotype and, therefore, all three became syntypes.

When Knowlton (1889) described Araucarioxylon arizonicum as a new species, he included one plate of line drawings and recorded the following as the original type description: "Annual ring not apparent to the naked eye, but under the microscope observed to be present, the yearly growths being separated by a layer of 2-5 tangentially compressed cells; tracheids with moderately thick walls, which are provided on the radial sides with a single row of large contiguous pores or rarely with two rows of alternating pores, and on the tangential sides with numerous, separated, perfectly round, small pores; medullary rays numerous, composed of a single series of 1-22 short, superimposed cells; resin ducts none." Considering the line drawings of Knowlton (1889) and the evidence gathered by re-examination of his original thin sections (Figs 2-4), it can be concluded that Knowlton's diagnosis of Araucarioxylon arizonicum actually comprised an eclectic combination of features present in all three logs, as detailed below.

In describing a PEFO tracheidoxyl considered to be a plesiotype of A. arizonicum, Daugherty (1941) considered that a "poorly defined growth ring" was present and that "bordered pits are usually arranged in a single linear series... When these pores are arranged in two series they alternate and are slightly, if at all, angled." It would appear that Daugherty (1941) examined woods similar to the Sherman log. Daugherty (1941) noted that cross-field pitting was "difficult of demonstration" and that Knowlton (1889) had encountered the same problem. These researchers evidently did not have available the resolving power of modern microscopes, because as shown in Figs 2-4, cross-field pitting was found without difficulty in the thin sections of all three syntypes investigated by Knowlton (1889). However, absence of cross-field pitting in a specimen of "Araucarioxylon arizonicum" was noted in a recent study (Ash \& Savidge 2004), and although its absence in 


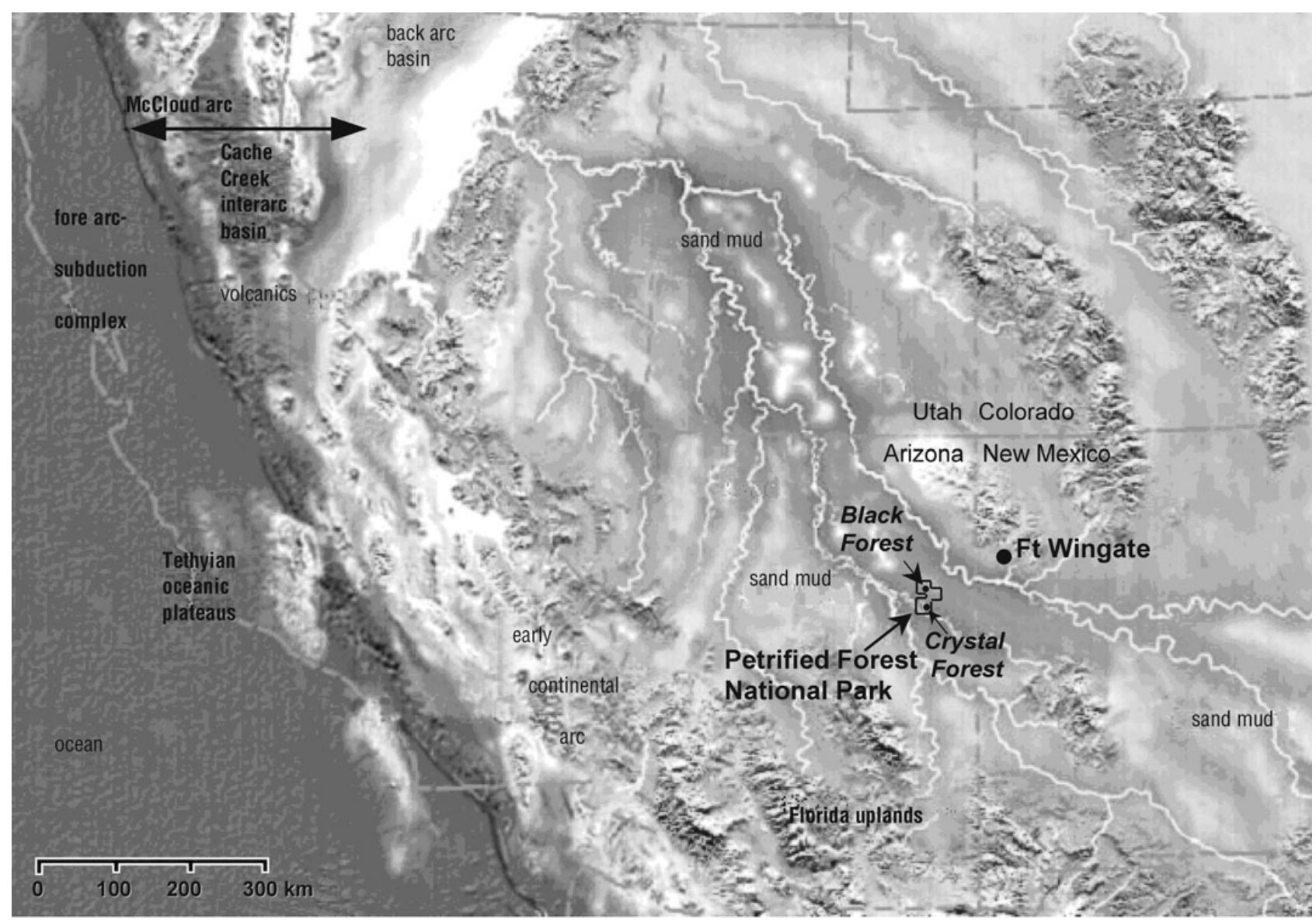

Figure 1. Late Triassic ( $220 \mathrm{Ma})$ landscape of southwestern USA, with state boundaries and positions of PEFO and Fort Wingate indicated (after R. Blakey, Northern Arizona U., by permission).

that specimen was interpreted as loss of detail due to excessive mineralization, it remains possible that there is a species entirely lacking in cross-field pitting.

\section{Materials and methods}

The geographical positions for the investigated specimens and an interpretation of the terrain existing in the region during Late Triassic when logs in the Crystal Forest region of PEFO were buried, are indicated in Fig. 1. As indicated in that figure, many of the fossil logs in the region evidently were deposited in generally northward flowing fluvial and lacustrine environments (Ash 1992).

A loan of the Araucarioxylon arizonicum Knowlton, 1889 syntypes was provided by the Smithsonian Institution (formerly known as the U.S. National Museum) in Washington, DC, USA (USNM). This loan comprised the original 10 thin sections prepared by Knowlton and also one small fragment of permineralized secondary xylem from the butt end of the specimen generally referred to as the "Sherman log" (USNM 30862). Anatomical details found in the 10 slides are shown in Figs 2-4 (one syntype per figure) as follows: Fig. 2 - slide USNM 34146a [also labeled \#69 (9A)] a cross section, slide \#70 (9A) a radial section, slide \#71 (9A) a tangential section, slide \#72 (9A) a second tangential section; Fig. 3 - slide USNM 34147a (also labeled \#73) a cross section, slide \#74 a radial section, slide \#75 a tangential section; Fig. 4 - slide USNM 30862a (also labeled \#76) a cross section, slide \#77 a radial section, and slide \#78 a tangential section.

Only three of the 10 slides provided by the Smithsonian Institution are inscribed with "USNM", but those three corrrespond to the identically numbered labels attending three logs under the care of the Smithsonian Institution. Handwritten notes within Knowlton's fossil wood section notebook (1885-1888, covering thin sections 1-308), clearly indicate that slides \#77 and \#78 were from the same $\log$ as that producing USNM 30862a slide \#76 (S. Ash, personal communication). After microscopic examination of thin sections prepared in-house from the loaned fragment of USNM 30862, it was confirmed that the anatomy in slides USNM 30862a \#76, \#77 and \#78 were in agreement with the features in the newly prepared slides and, as 
detailed below, distinct from those found in the slides prepared from the other two specimens. A "9A" designation is found only on slides USNM 34146a \#69 (9A), \#70 (9A), \#71 (9A) and \#72 (9A), and considering this and the general agreement in overall appearance of the thin section, those four slides (one transverse, one radial and two tangential sections) were assumed to all be from one specimen. By default, therefore, it was deduced that slides \#74 and \#75 were prepared from the log yielding USNM 34147a \#73. Unfortunately, the Smithsonian Institution would not provide fragments from logs USNM 34146 and USNM 34147 for preparation of confirmatory thin sections.

Knowlton (1889) recorded one of the black logs as having its larger cross sectional diameter (elliptical due to some compression of the stem) as $201 / 2 \times 13 \frac{1}{2}$ inches (approx. perimeter $=54.5$ inches), the smaller end being $17 \times 12$ inches (approx. perimeter $=46.2$ inches). Knowton (1889) recorded the second black log at its larger end to be $24 \times 16$ inches (approx. perimeter $=64.1$ inches), and $17 \times 12$ inches (approx. perimeter $=46.2$ inches) at the other end. Those two logs standing on display in the Smithsonian Institution were recently re-measured by J. Wingerath, Palaeobotany Collections Specialist at the Smithsonian Institution, using calipers to estimate maximum and minimum diameters of each end. The shorter one, USNM 34146, is $194 \mathrm{~cm}$ long and of elliptical cross section, its larger end being $56.2 \times 44.8 \mathrm{~cm}$ (approx. perimeter $=156 \mathrm{~cm}$, or 63 inches), its smaller end being $49.6 \times$ $29.9 \mathrm{~cm}$ (approx. perimeter $=128.6 \mathrm{~cm}$, or 50.6 inches). The other log, USNM 34147, is $238 \mathrm{~cm}$ long and also of elliptical cross section, its larger end being $50.8 \times$ $35.0 \mathrm{~cm}$ (approx. perimeter $=137 \mathrm{~cm}$, or 54 inches), its smaller end being $44.6 \times 32.7 \mathrm{~cm}$ (approx. perimeter $=$ $122.8 \mathrm{~cm}$, or 48.4 inches). It is apparent from both sets of measurements that the two black logs if placed end to end would not conform dimensionally. The basal end of the longer, smaller diameter black log (USNM 34147) is notably larger in circumference than the smaller end of the shorter, larger diameter black log (USNM 34146). There has been no obvious loss of material from the perimeters of the two; thus, it appears that erosion of the outer wood cannot account for the disconformity. In other words, if the two logs came from a single bole it was a very oddly shaped one, and the evidence instead points to the conclusion that the two logs came from distinct trees.

Samples of outermost secondary xylem of three putative A. arizonicum logs were obtained from the Crystal Forest region within Petrified Forest National Park (Fig. 1). Those three specimens, shown in Figs 5-7, are positioned at PEFO localities PFP 124 and 125 and were chosen randomly based solely on the log exhibiting external evidence for good anatomical preservation (i.e. tracheid radial files visible in transverse surfaces, ray flecks evident in radial surfaces).
Transverse, radial and tangential surfaces of the fossil woods were cut and ground to $30 \mu \mathrm{m}$ thickness for transmitted light microscopy. A stage micrometer (precision $\pm 2 \mu \mathrm{m}$ ) was used for measurements. The slides and uncut material removed from the fossils taken from the Crystal Forest are stored in Petrified Forest National Park under catalog numbers PEFO 34811-34819.

Anatomical features of the Upper Triassic woods investigated are summarized in Table 1. Unfortunately, very little quantitative data on wood anatomical features was included in the original type descriptions published by earlier researchers; therefore, data in Table 1 are limited to qualitative differences and some semi-quantitative estimates based on visual estimation as opposed to precise measurement. Terminology employed for cross-field oculipore pitting is sensu Phillips (1948) followed by Panshin \& de Zeuuw (1980) and Barefoot \& Hankins (1982), using Philippe (1995, pp. 47-49) for oopore classification.

Dimensional data on anatomical features of the six species diagnosed herein are given in the systematics section below. Distance measurements to the nearest $1 \mu \mathrm{m}$ were estimated from measurements made on enlarged prints of digitized images including those of a calibrated (0.01 mm precision) stage micrometer scale. Data provided in Table 1 on Arboramosa semicircumtrachea, Protocupressinoxylon arizonica and Ginkgoxylpropinquus hewardii were earlier published (Savidge 2006, Savidge \& Ash 2006). Additional permineralized secondary xylem morphotaxa in this region's Late Triassic beds include Woodworthia arizonica Jeffrey, 1910, Schilderia adamanica Daugherty, 1934, Dadoxylon chaneyi Daugherty, 1941, Lyssoxylon grigsbyi Daugherty, 1941, and Charmorgia dijolli Ash, 1985. These are not listed in Table 1 because they are anatomically quite distinct, but excepting Charmorgia dijolli (not a log, a 24-cm-diameter specimen but secondary xylem radial width is only $\sim 1 \mathrm{~cm}$ ), their salient features are briefly considered within the Appendix key.

A branch stub from the Crystal Forest Arboramosa semicircumtrachea holotype (locality number PFP 116 in the collection records of Petrified Forest National Park) was also obtained and sectioned, leading to the emended Arboramosa diagnosis herein. The slides and uncut material of this stub are stored in Petrified Forest National Park under catalog number PEFO 34160.

\section{Results}

Figs 2-4 are photomicrographs of secondary xylem features observed in A. arizonicum holotype (syntype) slides as prepared by Knowlton (1889), each figure showing details of a single specimen. Table 1 compares the qualita- 
tive anatomical features of the six investigated permineralized woods, also several that were earlier investigated (Savidge 2006, Savidge \& Ash 2006). By comparing the full set of anatomical features of each wood, it is evident that each morphotaxon is qualitatively different from all others listed.

Fig. 2 presents images of secondary xylem from the A. arizonicum Knowlton, 1889 syntype USNM 34146 here re-designated gen. nov. as lectotype Pullisilvaxylon arizonicum. This specimen was one of two "black" logs described by Knowlton (1889). The wood where examined in cross section appears to have been sheared sideways during petrifaction (Fig. 2A), but its radial files also display disorganization as a result of intrusive tip growth of differentiating cambial derivatives (Fig. 2B). The tracheids are thick-walled and generally rounded with large intercellular spaces (Fig. 2C), and the xylem shows evidence for growth interruptions (Fig. 2A, B). Axial parenchyma are rarely encountered (Fig. 2D). Radial walls of the tracheids have long chains of uniseriate bordered pits, mostly contacting and oblate (Fig. 2E, F) but sometimes spaced apart and rounded (Fig. 2G). This exclusively uniseriate pitting is an interesting diagnostic feature of woods of Pullisilvaxylon gen. nov.; neither bi-seriate nor multi-seriate pitting were seen. Rays are homocellular, thin-walled, uniseriate and of small height, comprising usually 2-10 but sometimes as many as 24 ray cells (Fig. 2H). In tangential walls, small-diameter pores (Fig. 2I) and half-sized bordered pits (Fig. 2J) are both present as additional highly diagnostic features. Oculipore long axes of the cross-field taxodioid pits are oriented nearly vertically, with only one to two rarely three pits per cross-field (Fig. 2K-M). Neither cross-field pitting nor axial parenchyma were described by Knowlton (1889), but the presence of conspicuous smalldiameter tangential-wall pores (Fig. 2I) and the absence of multi-seriate pitting in radial walls would have been ample justification for typing this specimen to a genus other than Araucaroxylon Kraus, 1870.

The images in Fig. 3 are of USNM 34147, a second "black" log that Knowlton (1889) regarded as a syntype of A. arizonicum and here designated as Pullisilvaxylon daughertii gen. nov. sp. nov. This specimen reportedly was collected in close proximity to lectotype Pullisilvaxylon arizonicum, and based on a comment by Hegewald (in Swaine \& Hegewald 1882) to the effect that both black logs were "of the same specimen," Knowlton (1889) considered that USNM 34147 and USNM 34146 had been produced by the same tree. However, as explained in the Methods section above, dimensionally the ends of the two logs do not fit together as might be expected, and although their wood anatomies are very similar (Table 1), notable differences exist between the two.

Secondary xylem of Pullisilvaxylon daughertii (Fig. 3A, B) has less thick-walled and generally smaller di- ameter tracheids than those in Pullisilvaxylon arizonicum. Pullisilvaxylon arizonicum secondary xylem has conspicously large intercellular spaces, whereas intercellular spaces are small and unobvious in Pullisilvaxylon daughertii. Ray height in terms of cell number is also shorter in Pullisilvaxylon daughertii. The tangential wall pores in Pullisilvaxylon arizonicum are mostly cupressoid oculipores, circular and 8-10 $\mu \mathrm{m}$ in diameter whereas those in Pullisilvaxylon daughertii are slightly elliptical mostly taxodioid oculipores about $5 \times 6 \mu \mathrm{m}$ in size. Pullisilvaxylon daughertii also differs from the arizonicum lectoype in lacking persuasive evidence for growth interruptions, having rays as viewed in cross section more closely spaced, and having slightly different cross-field pitting.

The preceding aside, Pullisilvaxylon daughertii shares with Pullisilvaxylon arizonicum the diagnostic feature of exclusively uniseriate radial-wall bordered pits (Fig. 3C-F) that are sometimes contacting and approaching an oblate shape (Fig. 3D, F) but equally or more often spaced and rounded (Fig. 3E). Cross-field pitting is taxodioid, although in places they appear as areolar oopores, the long axes of the apertures being oriented at about $60^{\circ}$, with $2-3$ pits in horizontal alignment per cross-field (Fig. 3G). The rays are generally short and homocellular, with 1-10 thin-walled cells per ray (Fig. 3H, I). Small-diameter ray cells are commonly within rays containing otherwise large diameter ray cells (Fig. 3I). The shape of the ray cells is variable (Fig. 3J). Tangential wall pitting is of two kinds, small-diameter pores (Fig. 3K) and weakly bordered pits slightly more than half the diameter of the radial wall pits (Fig. 3L). Bordered pits of similar diameter to those in the radial walls are also encountered in tangential walls, but they are uncommon and probably due to tracheid tip radial walls having been twisted into the tangential plane.

Fig. 4 is secondary xylem of USNM 30862 otherwise known as the 'Sherman log' and here re-designated nomen novum as Chinleoxylon knowltonii gen. nov. sp. nov. This specimen was described by Knowlton (1889) as having been collected at a site near Fort Wingate, New Mexico, approximately $125 \mathrm{~km}$ northeast of PEFO (Fig. 1). In both Knowlton's slides and my newly prepared thin sections, the wood is less well preserved than that seen in the other two syntypes. Secondary xylem of the Sherman log is moderately dense and variably organized without convincing evidence for growth interruptions (Fig. 4A, B). An extraordinarily diagnostic although not everywhere readily seen feature found in cross sections of Chinleoxylon knowltonii wood is its abrupt doubling of radial files, followed by reversion to a single radial file in the next tier of tracheids (Fig. 4C). Radial wall bordered pits in this wood are not particularly abundant and are mixed uniseriate/bi-seriate (Fig. 4D-G). When bi-seriate the pits are mostly circular 
Table 1. Anatomical features of the investigated woods

\begin{tabular}{|c|c|c|c|c|}
\hline Morphotaxon: & $\begin{array}{c}\text { Pullisilvaxylon arizonicum } \\
\text { USNM } 34146\end{array}$ & $\begin{array}{c}\text { Pullisilvaxylon daughertii } \\
\text { USNM } 34147\end{array}$ & $\begin{array}{c}\text { Chinleoxylon knowltonii } \\
\text { USNM } 30862\end{array}$ & $\begin{array}{l}\text { Silicisilvaxylon } \\
\text { imprimicrystallus }\end{array}$ \\
\hline & (Fig. 2) & (Fig. 3) & (Fig. 4) & (Fig. 5) \\
\hline \multicolumn{5}{|l|}{ Tracheidoxyl Features } \\
\hline growth interruptions & yes & indefinite & indefinite & yes \\
\hline estimated density ( $\mathrm{X}$ section) & medium to high & low to medium & medium & low to medium \\
\hline axial parenchyma present & yes & not found & yes & not found \\
\hline \multirow[t]{2}{*}{ extraordinary features } & cupressoid oculipores & taxodioid oculipores & momentary doubling & resinous tracheids \\
\hline & in tangential walls & in tangential walls & of tracheid radial files & incipient resin canals \\
\hline \multicolumn{5}{|l|}{ Tracheids } \\
\hline radial file organization & variable & mostly ordered & variable & mostly ordered \\
\hline X-sectional shape & rounded/angular & mostly angular & mostly angular & rounded/angular \\
\hline tracheid lumen shape & rounded/angular & mostly angular & mostly angular & rounded/angular \\
\hline intercellular spaces & common, large & inconspicuous & inconspicuous & common, small \\
\hline radial wall thickness & thick & thin to medium & medium & medium \\
\hline tangential wall thickness & thick & thin to medium & medium & medium \\
\hline resinous tracheids & not found & not found & not found & common \\
\hline \multicolumn{5}{|l|}{ Bordered pits } \\
\hline Radial wall bordered pits & abundant & abundant & present & present \\
\hline chain length & long & medium & short & long \\
\hline uniseriate & common & common & present & common \\
\hline bi-seriate alternating & not found & not found & common & common \\
\hline bi-seriate opposite & not found & not found & not found & common \\
\hline tri-seriate & not found & not found & not found & not found \\
\hline circular, not contacting & common & dominant & rare & rare \\
\hline oblate, contacting & dominant & common & rare & common \\
\hline bi-seriate contacting/angular & not applicable & not applicable & common & dominant \\
\hline bi-serate separated/rounded & not found & not found & present & rare \\
\hline half-bordered pits & yes & yes & yes & yes \\
\hline Tangential wall bordered pits & present, uncommon & common & common & rare \\
\hline chain length & short & short & medium & short \\
\hline uniseriate & yes & yes & yes & yes \\
\hline bi-seriate & not found & not found & not found & not found \\
\hline circular, not contacting & dominant & dominant & not found & not found \\
\hline oblate, contacting & not found & not found & yes & present \\
\hline angular contacting & not found & not found & not found & not found \\
\hline size relative to radial wall pits & half-sized & half- and full-sized & equal & equal \\
\hline \multicolumn{5}{|l|}{ Rays } \\
\hline ray frequency (cross) & medium & medium & medium & medium \\
\hline ray frequency (tangential) & medium to high & high & high & high \\
\hline ray height (cell no.) & medium ( 2 to 24 ) & short (1 to 10$)$ & medium (2 to 24) & short (1 to 18 ) \\
\hline ray cell tangential width & large & small or large & medium & small or large \\
\hline ray cell tangential shape & oblate-elliptical & variable & upright-flattened & mostly flattened \\
\hline ray cell swollen/barrel-shaped & no & no & no & yes \\
\hline ray cell-wall thickness & thin & thin & thin & thin or thick \\
\hline uniseriate & yes & yes & yes & yes \\
\hline bi-seriate & not found & not found & not found & partially bi- tri-seriate \\
\hline heterocellular & not found & yes & not found & yes \\
\hline horizontal pitting & not found & not found & not found & not found \\
\hline Cross-field pits & taxodioid & taxodioid & taxodioid & taxodioid, cupressoid \\
\hline no. pits/crossfield & 1 to 2 & 2 to 3 & 6 to 8 & 2 \\
\hline arrangement & centered & 1 horizontal row & 2 horizontal rows & 1 horizontal row \\
\hline aperture orientation & $\sim 80^{\circ}$ & $60-70^{\circ}$ & $\sim 45^{\circ}$ & circular and $\sim 70^{\circ}$ \\
\hline
\end{tabular}




\begin{tabular}{|c|c|c|c|c|c|}
\hline Morphotaxon: & $\begin{array}{c}\text { Silicisilvaxylon } \\
\text { secundacrystallus }\end{array}$ & $\begin{array}{l}\text { Crystalloxylon } \\
\text { imprimicrystallus }\end{array}$ & $\begin{array}{c}\text { Arboramosa } \\
\text { semicircumtrachea }\end{array}$ & $\begin{array}{c}\text { Protocupressinoxylon } \\
\text { arizonica }\end{array}$ & $\begin{array}{c}\text { Ginkgoxylpropinquus } \\
\text { hewardii }\end{array}$ \\
\hline & (Fig. 6) & (Fig. 7) & (see Savidge \& Ash 2006) & (see Savidge 2006) & (see Savidge 2006) \\
\hline \multicolumn{6}{|l|}{ Tracheidoxyl Features } \\
\hline growth interruptions & indefinite & yes & yes & rings conspicuous & indefinite \\
\hline estimated density (X section) & low & medium & medium & low to medium & high \\
\hline axial parenchyma present & not found & not found & yes & yes & not found \\
\hline extraordinary features & $\begin{array}{c}\text { bi-seriate ray cells, } \\
\text { arrangement }\end{array}$ & $\begin{array}{c}\text { abundant pitting, } \\
\text { no half-bordered pits }\end{array}$ & $\begin{array}{l}\text { semicircular tracheids } \\
\text { circumferential pits }\end{array}$ & $\begin{array}{c}\text { growth rings, } \\
\text { heterocellular rays }\end{array}$ & $\begin{array}{c}\text { swollen ray cells, } \\
\text { large diameter cells }\end{array}$ \\
\hline \multicolumn{6}{|l|}{ Tracheids } \\
\hline radial file organization & ordered & ordered & disordered & ordered & disordered \\
\hline X-sectional shape & rounded/angular & mostly angular & rounded+straight side & angular & angular/variable \\
\hline tracheid lumen shape & rounded/angular & mostly rounded & rounded+straight side & rounded/angular & mostly angular \\
\hline intercellular spaces & common, small & common, small & common, small & rare, small & rare, small \\
\hline radial wall thickness & medium & thick & thick & medium & medium \\
\hline tangential wall thickness & medium & thick & thick & medium & medium \\
\hline resinous tracheids & not found & not found & not found & not found & not found \\
\hline \multicolumn{6}{|l|}{ Bordered pits } \\
\hline Radial wall bordered pits & abundant & very abundant & abundant & abundant & abundant \\
\hline chain length & long & short & long & long & long \\
\hline uniseriate & dominant & rare & common & dominant & dominant \\
\hline bi-seriate alternating & common & dominant & common & rare & common \\
\hline bi-seriate opposite & not found & not found & present, rare & not found & not found \\
\hline tri-seriate & not found & present & rare & not found & not found \\
\hline circular, not contacting & dominant & common & common & rare & dominant \\
\hline oblate, contacting & common & rare & common & dominant & not found \\
\hline bi-seriate contacting/angular & rare & rare & rare & common & not found \\
\hline bi-serate separated/rounded & common & dominant & not found & not found & common \\
\hline half-bordered pits & yes & not found & yes & yes & yes \\
\hline Tangential wall bordered pits & common & rare & common & rare & not found \\
\hline chain length & short & short & long & short & not applicable \\
\hline uniseriate & yes & yes & yes & yes & not applicable \\
\hline bi-seriate & not found & not found & rare & not found & not applicable \\
\hline circular, not contacting & dominant & not found & yes & not found & not applicable \\
\hline oblate, contacting & present & not found & yes & yes & not applicable \\
\hline angular contacting & not found & not found & rare & not found & not applicable \\
\hline size relative to radial wall pits & equal & equal & equal & equal & not applicable \\
\hline \multicolumn{6}{|l|}{ Rays } \\
\hline ray frequency (cross) & medium & medium & low & low & high \\
\hline ray frequency (tangential) & high & medium & low & low & high \\
\hline ray height (cell no.) & short/medium ( 1 to 25$)$ & long ( 2 to 40$)$ & short ( 1 to 15 ) & short ( 1 to 10$)$ & short (1 to 16 ) \\
\hline ray cell tangential width & small & large & large & large & small \\
\hline ray cell tangential shape & variable & upright ellipses & upright ellipses & circular-oblate & upright ellipses \\
\hline ray cell swollen/barrel-shaped & rarely & no & no & no & yes \\
\hline ray cell-wall thickness & thin & thin & thin & thin & thin \\
\hline uniseriate & yes & yes & yes & yes & yes \\
\hline bi-seriate & partially bi-seriate & rarely & not found & partially bi-seriate & partially bi-seriate \\
\hline heterocellular & not found & not found & not found & yes & not found \\
\hline horizontal pitting & not found & not found & yes & not found & not found \\
\hline Cross-field pits & cupressoid, taxodioid & taxodioid, cupressoid & taxodioid, cupressoid & cupressoid & cupressoid \\
\hline no. pits/crossfield & 2 & 3 to 6 & 1 to 6 & 1 to 4 & 1 to 3 \\
\hline arrangement & 1 horizontal row & 1 horizontal row & 1 or 2 horizontal rows & irregular & irregular \\
\hline aperture orientation & circular & $\sim 70^{\circ}$ & $\sim 45^{\circ}$ & variable, mostly $\sim 80^{\circ}$ & variable, mostly $\sim 80^{\circ}$ \\
\hline
\end{tabular}


but may be somewhat hexagonal in outline and in alternate packing (Fig. 4D-F). The presence of bi-seriate bordered pits in USNM 30862 clearly differentiates this wood from USNM 34146 and USNM 34147 ( $c f$. Figs 2, 3). The biseriate pitting commonly co-occurs in the same radial walls with uniseriate chains of circular and contacting or, rarely, oblate and contacting pits (Fig. 4E), but uniseriate pitting also occurs independently of bi-seriate pitting (Fig. 4G). Cross-field pits have their long axes oriented $\sim 45^{\circ}$, with usually $6-8$, rarely as few as 2 , well-separated cupressoid pits in one or two somewhat disorganized 'horizontal' rows (Fig. 4H). In tangential section, the abundant rays are homocellular and may contain as many as 24 thin-walled cells per ray, although the majority are half or less that size, and rays having as few as two cells are common (Fig. 4I, J). However, single-celled rays were not seen. Numerous mainly uniseriate bordered pits of similar diameter to those in the radial walls are present in tangential walls (Fig. 4K-M), but small-diameter pores were not found in this specimen. Axial parenchyma cells are present but not abundantly (Fig. 4N).

Fig. 5A shows an overview of a randomly sampled large diameter log situated in the Crystal Forest region of Petrified Forest National Park and here designated Silicisilvaxylon imprimicrystallus gen. et sp. nov. The bole length from the root collar until where the upper ends of the log breaks into small pieces is $8.7 \mathrm{~m}$. At the root collar the swollen bole base is elliptical, $50 \mathrm{~cm}$ in narrowest and $140 \mathrm{~cm}$ in widest 'diameter', and at the $8.7 \mathrm{~m}$ position where the surface wood was sampled the roughly circular bole diameter is $65 \mathrm{~cm}$. Pith diameter at the sampling position is $<1 \mathrm{~cm}$. Below the root collar a tapering taproot displays a maximum diameter of $50 \mathrm{~cm}$, and at least one lateral root of large diameter egresses from the root collar. The bole surface exhibits pronounced longitudinal furrows (Fig. 5A). The secondary xylem is generally well-organized and has growth interruptions, conspicuous resinous tracheids particularly in association with those growth interruptions, and closely spaced rays that are mostly uniseriate but also commonly bi- and tri-seriate (Fig. 5B, C). Intercellular spaces are small but readily found among the tracheids (Fig. 5C, D). Radial wall bordered pits are variable, uniseriate and bi-seriate, partially angular in outline where bi-seriate and contacting, also circular to oblate within uniseriate chains and commonly mixed uniseriate/bi-seriate (Fig. 5E). When of bi-seriate rank, the pits may be either alternately (Fig. 5F) or oppositely (Fig. 5G) arranged within the same tracheid radial wall. When uniseriate they are generally oblate in long contiguous chains (Fig. 5H). Cross-field pitting is typically two conspicuously large taxodioid oculipores per cross field; however, they sometimes present as podocarpioid/dacrydioid pits and sometimes as cupressoid pits (Fig. 5H, I). Viewed in tangential section, rays in the outer wood of this large-diameter log are generally short, 8-10 cells high but ranging from 1 to 18 cells (Fig. 5J). As a useful diagnostic feature, many of those short rays are fusiform shaped, partially bi- or tri-seriate, and appear as incipient horizontal resin canals (Fig. 5J, K); however, no convincing evidence for actual horizontal (or vertical) resin canals was seen. Most rays are homocellular and contain large diameter cells with only moderately thickened walls.

These cells are noticeably flattened beyond what can be considered oblate, although oblate and circular-shaped ray cells are also present. Heterocellular rays also occur and in tangential section contain sideways bulging cells similar to those in homocellular rays, but they also exhibit small-diameter cells with very thick walls, sometimes positioned at one or both ends of a ray and also within the ray. Resinous tracheids, partially bi- and tri-seriate rays, bi-seriate pitting often oppositely as well as alternatiely arranged, and the nature of cross-field pitting serve to make this specimen entirely distinct from the Chinleoxylon and Pullisilvaxylon species described above (Table 1 and Appendix).

Fig. 6A shows a second randomly sampled specimen, here designated Silicisilvaxylon secundacrystallus gen. et sp. nov. Note that like Silicisilvaxylon imprimicrystallus gen. et sp. nov., this specimen also has longitudinal although somewhat less pronounced furrows along the surface of its bole (Fig. 6A). The bole length from the root collar until where the upper end of the log breaks into small pieces is $11.6 \mathrm{~m}$. The swollen bole base at the root collar is elliptical, $50 \mathrm{~cm}$ in narrowest and $140 \mathrm{~cm}$ in widest 'diameter', and at the $11.6 \mathrm{~m}$ position where the surface xylem was sampled it is $35 \times 60 \mathrm{~cm}$. Pith diameter at the sampling position is $<1 \mathrm{~cm}$. Below the root collar a $1.5 \mathrm{~m}$ long (before burial) tapering taproot has root-collar diameter $\sim 40 \mathrm{~cm}$, and several large-diameter lateral roots egress from the root collar. Its secondary xylem is well organized, lacks convincing evidence for growth interruptions, and has moderately to widely spaced uniseriate rays (Fig. 6B, C). Intercellular spaces between tracheids are common and may be either small or large (Fig. 6D, E). Both tangential and radial wall bordered pits are present. In tangential walls the bordered pits are in very short chains and invariably uniseriate, whereas in radial walls the bordered pits occur in bi-seriate as well as uniseriate rank (Fig. 6F-I). Radial wall bordered pits when uniseriate are rounded and well-separated (Fig. 6H), and when bi-seriate they alternate and are rounded and separated or oblate (Fig. 6I). Cross-field pits are mostly cupressoid sometimes taxodioid with apertures circular or oriented nearly vertically (Fig. 6J). Rays are thin-walled homocellular, between 1-25 cells in height, and often partially bi-seriate (Fig. 6K). Where bi-seriate, ray cells have the novel attribute of being alternately rather than oppositely arranged; in other words, 
within-ray organization is not tight. In some uniseriate rays, individual ray cells are spaced $\sim 10 \mu \mathrm{m}$ apart (Fig. $6 \mathrm{~L}$ ). Silicisilvaxylon secundacrystallus is quite similar to Silicisilvaxylon imprimicrystallus, but the two are here considered as distinct species because $S$. secundacrystallus lacks the incipient resin canals, resinous tracheids and opposite bi-seriate pitting found in Silicisilvaxylon imprimicrystallus.

Fig. 7A shows a third randomly sampled specimen, here designated Crystalloxylon imprimicrystallus gen. nov. sp. nov. The log displays some form of surface erosion along its upper length, and the butt end of the log has a centralized cavity not evident at the upper end of the log and possibly due to heartrot before petrifaction occurred (Fig. 7A). The bole surface in general is darkened and the upper surface in places blackened. The bole is broken into a number of segments and displays an overall estimated length from the swollen root collar to where the smaller end of the log disappears into sedimentary rock of $20 \mathrm{~m}$. In places branch scars are closely clustered around the circumference perhaps indicative of whorls. Root collar diameter was estimated at $70 \times 102 \mathrm{~cm}$, and the diameter where the top enters rock at $\sim 50 \mathrm{~cm}$. Where the surface xylem was sampled, the bole is $40 \times 72 \mathrm{~cm}$, and pith diameter at that position is $<1 \mathrm{~cm}$. A taproot could not be discerned, probably due to breakdown of the megafossil. The secondary xylem is well organized, has growth interruptions and uniformly thick-walled, partially rounded to angular tracheids (Fig. 7B). Small intercellular spaces are common but not always evident (Fig. 7C). A useful diagnostic feature for readily identifying this taxon resides in the small canals penetrating through the tracheid secondary walls and linking with the oculipores in the ray cell walls (Fig. 7D). The homocellular uniseriate widely spaced rays comprise a mixture of short to long rays ranging from 2-40 cells (Fig. 7B, E). The thin-walled ray cells are shaped as upright ellipses (Fig. 7F). Not uncommonly, single positions in the uniseriate ray tier alter to bi-seriate with the two cells placed oppositely. The specimen has a marked prevalence of principally bi-seriately arranged radial wall bordered pits (Fig. 7G, H). Limited uniseriate (Fig. 7I) and even more rarely tri-seriate pitting were also noted. Cross fields display two to three taxodioid or cupressoid pits, usually in a single horizontal row, with aperture long axes inclined steeply (Fig. 7I). Tangential wall bordered pits are present but rarely seen and of similar diameter to those in radial walls.

Based on the above observations supplemented by the anatomical details provided by Daugherty (1936, 1941), Gould (1971) and my own observations, a key to aid in the diagnosis of the various tracheidoxyl morphotaxa of Late Triassic southwestern USA was developed (Appendix).

\section{Systematic palaeontology}

\section{Pullisilvaxylon gen. nov.}

Type. - Pullisilvaxylon arizonicum (Knowlton) comb. n., specimen USNM 34146.

Diagnosis. - In cross section, secondary xylem pycnoxylic, uniseriate rays, tracheid radial files more or less organized, axial parenchyma if present are scarce, intercellular spaces of varied size; in radial section, long chains of uniseriate-only bordered pits, pits mostly contacting and of oblate outline but also rounded and well spaced, cupressoid cross-field pitting with long axes oriented nearly vertically, one to three oculipores in one row per crossfield. In tangential section, both small-diameter oculipores and bordered pits of less than one-half the diameter of radial wall bordered pits common in tracheid walls, rays uniseriate, homocellular, thin-walled, mostly short $(<10$ cells $)$.

Etymology. - L. pullus - dark-coloured or blackish; L. silva - forest; L. xylon - wood.

Occurrence. - Pullisilvaxylon denotes permineralized logs localized in the Black Forest bed of the Chinle Formation (Fig. 1). The historical record indicates that this and a second specimen (Pullisilvaxylon daughterii gen. et sp. nov., described below and shown in Fig. 3) originated in the Lithodendron Wash region of the Black Forest Bed. Hegewald (in Swaine \& Hegewald 1882) wrote: "I encountered considerable diffficulty in trying to procure two specimens answering to the General's description, and which I thought would please. After finding the larger of the two fossils sent, I could find no mate, the remainder being of a different species, and the exposed part broken in segments too short to answer. Finally, I concluded to unearth part of the same specimen ... This was on the right bank of Lithodendron, 1 1/4 miles from Bear Spring." That location although not precisely known generally agrees with the locale of the Black Forest Bed within Petrified Forest National Park (Parker 2006), and logs associated with the Black Forest Bed generally exhibit distinctively black wood (Ash 1992). Questions concerning the location and stratum where this lectotype was obtained are exacerbated by the following comments (made by P.T. Swaine, in Swaine \& Hegewald 1882): "Only one of the two specimens obtained from the Lithodendron by Lieutenant Hegewald was forwarded to Washington. This is the large dark-colored one. In the place of the second one brought in from the locality of the Lithodendron a better specimen was found on the mesa to the north of and adjacent to Fort Wingate, about 2 miles from the flag-staff. This is the smaller and lighter-colored one." Knowlton (1889) 
believed that both dark logs had "probably came from Lithodendron, in Arizona" because they were both "black throughout".

Remarks. - In having strictly uniseriate bordered pits in their radial walls and a combination of small-diameter oculipores and half-sized bordered pits in their tangential walls, woods of the genus Pullisilvaxylon are far removed from the Araucaroxylon Kraus, 1870 type. The rounded uniseriate ('abietinoid') character of Pullisilvaxylon bordered pits shows a definite tendency away from Agathoxylon or Dadoxylon types, and it can be suggested that Pullisilvaxylon morphotypes represent a crucial step in the evolutionary sequence.

Pullisilvaxylon arizonicum (Knowlton, 1889) comb. nov. Figure 2

Basionym. - Araucarioxylon arizonicum Knowlton, 1889, U.S. National Museum Proceedings 1888, 11, 1-4, pro parte.

Lectotype. - This specimen resides in the Smithsonian Institution, Washington, DC, as USNM 34146. Catalog numbers for thin-section lectotype: USNM 34146a \#69 (9A) cross section. Paratypes: \#70 (9A) - radial section, \#71 (9A) - tangential section and \#72 (9A) - tangential section. All of these slides are stored in the Smithsonian Institution.

Emended diagnosis. - Pycnoxylic secondary xylem, anatomy conforming to features diagnostic of the Pullisilvaxylon genus; radial file organization variable, in places poor; tracheids in cross section large, rounded, diameters to $70+\mu \mathrm{m}$ radial and $60+\mu \mathrm{m}$ tangential, lumens $40+\mu \mathrm{m}$ also rounded, secondary walls $10 \mu \mathrm{m}$ across, large intercellular spaces, scattered axial parenchyma; in radial section, long chains of contacting, oblate uniseriate bordered pits, spaced and circular uniseriate bordered pits also present, $1-2$ taxodioid pits $\left(8 \times 3 \mu \mathrm{m}\right.$, slanted at $\left.80^{\circ}\right)$ per cross field; in tangential walls, bordered pits infrequent and of same diameter $(\sim 18 \mu \mathrm{m}$, apertures $\sim 5 \mu \mathrm{m})$ as radial wall pits; mostly cupressoid sometimes taxodioid circular pores $(\sim 10 \mu \mathrm{m})$ with circular apertures $(\sim 3 \mu \mathrm{m})$ abundant, spaced well apart throughout tangential walls; rays uniseriate, medium length, 2-24 cells, homocellular, thin-walled, ray cells 20-40 $\mu \mathrm{m}$ tangential diameter, 30-70 $\mu \mathrm{m}$ axial diameter.
Etymology. - Arizonicum, epithet of a taxon formerly referred to as Araucarioxylon arizonicum Knowlton, 1889.

Remarks. - This fossil according to somewhat equivocal historical records is one of two black petrified logs from southwestern USA first to have its secondary xylem well described anatomically. It has anatomical features quite similar but nevertheless distinct from the other black log, Pullisilvaxylon daughertii gen. et sp. nov. (described below). Differences in xylem density, secondary wall thickness, radial wall pitting, ray height, tangential wall pitting and cross-field pitting serve to resolve the two.

\section{Pullisilvaxylon daughertii gen. et sp. nov.}

Figure 3

Holotype. - Specimen USNM 34147, residing in the Smithsonian Institution, Washington, DC. Catalog numbers for holotype slide: USNM 34147a \#73 (cross section). Paratypes: \#74 (radial section), \#75 (tangential section). These slides are stored in the Smithsonian Institution.

Diagnosis. - Secondary xylem anatomy conforming to features diagnostic of the Pullisilvaxylon genus; pycnoxylic organized to well-organized secondary xylem, tracheids in cross section rounded, diameters to $65 \mu \mathrm{m}$ radial and $65 \mu \mathrm{m}$ tangential, rounded lumens to $50 \mu \mathrm{m}$, tracheid double-wall thickness 10-12 $\mu \mathrm{m}$, cross sectional dimension of radial wall bordered pit pairs $\sim 12 \mu \mathrm{m}$ and often projecting beyond the secondary walls, uniseriate rays closely spaced; in radial section, uniseriate contacting and non-contacting rounded and oblate bordered pits ( $18 \mu \mathrm{m}$ diameter, apertures $\sim 5 \mu \mathrm{m}$ ), often oblate although non-contacting, crossfield pitting 2-3 horizontally aligned taxodioid oculipores or areolar oopores $(7 \times 3 \mu \mathrm{m})$, long axes slanted at $60-70^{\circ}$; in tangential section, rays short, uniseriate $1-10$ thinwalled cells, mostly flattened (10-30 $\mu$ m tangential diameter, 20-30 $\mu \mathrm{m}$ axial diameter), heterocellular because individual small-diameter ray cells are included within otherwise large diameter groupings, infrequent rounded spaced uniseriate both small $(\sim 10 \mu \mathrm{m})$ and full-sized $(16-18 \mu \mathrm{m}$, apertures $\sim 5 \mu \mathrm{m}$ ) tangential-wall bordered pits, also widely spaced taxodioid oculipores $(\sim 5 \times 6 \mu \mathrm{m}$, apertures $\sim 4$ m long).

Etymology. - Daughertii, acknowledging the efforts of Lyman H. Daugherty. In a description of what he considered

Figure 2. Lectotype Pullisilvaxylon arizonicum nov. gen. nov. sp., specimen USNM 34146. • A-C - cross section USNM 34146a \#69(9A), medium to high density partly disorganized xylem with thick-walled tracheids and uniseriate rays, C showing intercellular spaces. $\bullet$ D-G - radial section \#70(9A), D showing axial parenchyma cells, E-G - uniseriate bordered pits. $\bullet$ H-J - tangential section \#70(9A) showing uniseriate rays and cupressoid oculipores (I, one arrowed) and half-diameter bordered pits (J). $\bullet \mathrm{K}-\mathrm{M}$ - radial section \#70(9A), showing taxodioid cross-field pitting. 

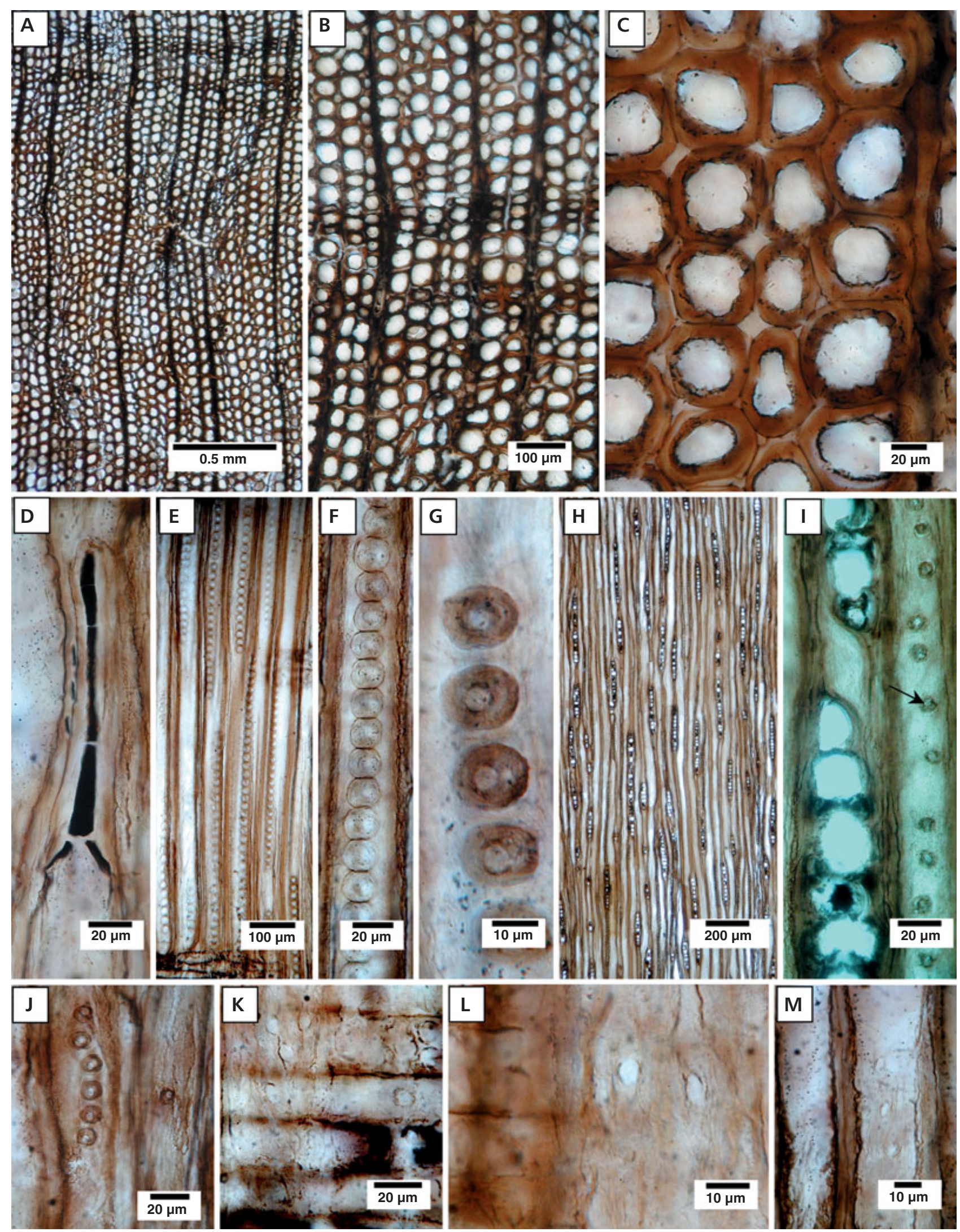
to be a plesiotype of Araucrioxylon arizonicum, Daugherty (1941) examined a fossil having tangential-wall pores very like this US National Museum specimen, and he clearly appreciated the diagnostic value of those pores.

Remarks. - This specimen is one of two dark petrified logs from southwestern USA first to have its secondary xylem well described anatomically. It has anatomical features quite similar but nevertheless convincingly distinct from the other "black" log (Pullisilvaxylon arizonicum gen. et sp. nov.). Differences in xylem density, secondary wall thickness, radial wall pitting, ray height, tangential wall pitting and cross-field pitting serve to resolve the two. In general, cell dimensions and intercellular spaces of Pullisilvaxylon daughertii are not as large or obvious as those in Pullisilvaxylon arizonicum; nevertheless, radial wall bordered pits when viewed in cross section are much more conspicuous in Pullisilvaxylon daughertii because of the former's relatively thin secondary walls.

\section{Chinleoxylon gen. nov.}

Type. - Chinleoxylon knowltonii gen. et sp. nov.

Diagnosis. - In cross section, pycnoxylic secondary xylem variably organized, generally large diameter tracheids with thin or moderately thick mostly angular secondary walls and few intercellular spaces; uniseriate rays; scattered, infrequent axial parenchyma. In radial section, bordered pits variably arranged, when bi-seriate alternating but usually circular rather than angular in outline, when uniseriate rounded or if contacting oblate; cross-field pits mostly taxodioid. In tangential section, scattered uniseriate bordered pits of similar diameter to those in radial walls, rays homocellular, thin-walled.

Etymology. - Chinle + L. xylon $=$ wood. Chinleoxylon recognizes the abundant petrified logs found in the Chinle Formation.

Occurrence. - Holotype Chinleoxylon knowltonii (informally known as the 'Sherman log') is housed in the Maryland storage facility of the Smithsonian Institution. Petrified woods collected in 1849, 1851 and 1853 from the Chinle Formation were the first plant fossils to be collected for scientific study from the region (Whipple et al. 1855, Knowlton 1889, Daugherty 1941, Ash 1972); ho- wever, all of those early collections evidently have been lost (S. R. Ash, personal communication). As indicated in Fig. 1, the Chinle Formation extends more than $1500 \mathrm{~km}$ east-west in southwestern USA as a collection of fluvial, lacustrine and floodplain rocks deposited in a back-arc basin formed inland of a magmatic arc off the west coast of North America during the Late Triassic when the climate was "humid or subhumid to semiarid" (Woody 2006). Chinleoxylon species may be distributed throughout the Chinle Formation.

Remarks. - The wood anatomy in Chinleoxylon gen. nov. is distinct from that in all previously described morphotaxa in showing abrupt, discontinuous doubling of tracheid radial files. Chinleoxylon gen. nov. is distinct from Pullisilvaxylon gen. nov. in having both uniseriate and bi-seriate pitting, larger rays and generally a larger number of small taxodioid oculipores per cross-field.

\section{Chinleoxylon knowltonii gen. et sp. nov.} Figure 4

Holotype. - This specimen, USNM 30862, is housed in the Maryland storage facility of the Smithsonian Institution, Washington, DC. Catalog number for holotype thin-section slide: USNM 30862a \#76 (cross section). Paratypes: \#77 (radial section), and \#78 (tangential section). These slides are stored in the Smithsonian Institution.

Diagnosis. - Secondary xylem anatomy conforms to features diagnostic of genus Chinleoxylon, radial files not well organized, tracheid diameters large (to $70 \mu \mathrm{m}$ radial, $65 \mu \mathrm{m}$ tangential), secondary walls 5-7 $\mu \mathrm{m}$, bi-seriate bordered pits more abundant than uniseriate in radial walls, bordered pits in tangential walls uniseriate only and of same diameter $(\sim 18 \mu \mathrm{m}$, apertures $6 \mu \mathrm{m})$ as radial wall pits, tracheid radial files in cross section commonly though not frequently abruptly doubled followed by reversion to a single radial file in the next tier; rays of moderate height, ray cells $15-30 \mu \mathrm{m}$ in diameter, thin-walled, upright; $7-8$ sometimes fewer taxodioid pits $\left(6.5 \times 4 \mu \mathrm{m}\right.$, slanted at $\left.45^{\circ}\right)$ per cross field.

Etymology. - Knowltonii recognizes efforts made by Knowlton $(1889,1890)$ to typify logs provided the U.S. National Museum by P.T. Swaine and J.F.C. Hegewald.

Figure 3. Pullisilvaxylon daughertii nov. gen. nov. sp., specimen USNM 34147. • A-C - cross section USNM 34147a \#73, well organized low to medium density xylem with moderately thick-walled tracheids, uniseriate rays and conspicuous radial wall bordered pits. $\bullet$ D-G - radial section \#74, showing uniseriate bordered pits (D-F) and taxodioid cross-field pitting $(\mathrm{G}) \cdot \bullet \mathrm{H}-\mathrm{L}-$ tangential section \#75, showing rays (H-J), taxodioid oculipores (K) and reduced-size bordered pits (L). 

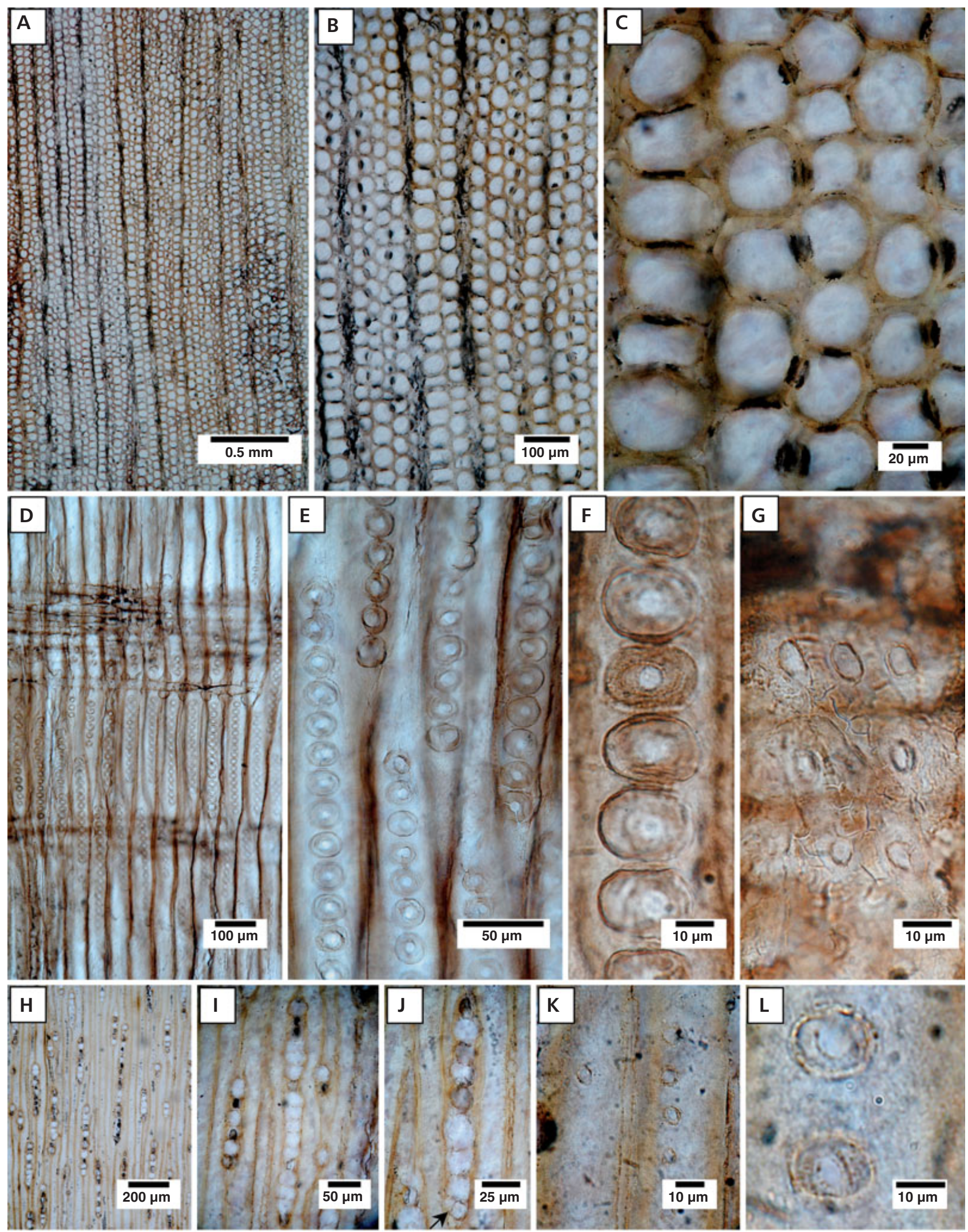
Occurrence. - Concerning the three petrified logs that Knowlton (1889) considered as syntypes of Araucarioxylon arizonicum, the records unfortunately indicate that only two were provided (Swaine \& Hegewald 1882), and Knowlton therefore encountered the difficulty of having to account for the origin of the third. This uncertainty remains today. However, USNM 30862 evidently is not in question, because it is "the smaller and lighter-colored" log (the other two were described as "black") referred to by Swaine (in Swaine \& Hegewald 1882) as having been obtained about 2 miles north of Fort Wingate, approximately $125 \mathrm{~km}$ northeast of Lithodendron Wash in Petrified Forest National Park (Fig. 1). The logs were obtained for the U.S. National Museum at the request of General Sherman, and the one labeled as USNM 30862 has long been known as the 'Sherman log' (J.G. Wingerath, personal communication).

Remarks. - Article 52.1. of the Code states that "A name, unless conserved (Art. 14) or sanctioned (Art. 15), is illegitimate and is to be rejected if it was nomenclaturally superfluous when published, i.e. if the taxon to which it was applied, as circumscribed by its author, definitely included the type (as qualified in Art. 52.2) of a name which ought to have been adopted, or of which the epithet ought to have been adopted, under the rules (but see Art. 52.3)." As explained in the History section above, Araucarioxylon has been concluded to be nomen superfluum. In addition, the three specimens considered by Knowlton (1889) as Araucarioxylon arizonicum syntypes are anatomically diverse, Chinleoxylon knowltonii gen. et sp. nov. being readily resolved from the other two by its bi-seriate bordered pits, transiently doubled radial files and absence of tangential wall pores. Abrupt, discontinuous radial file doubling does not appear to be explainable in terms of intrusive growth of fusiform cambial cell tips, rather appears to have its explanation in the occurrence of an anticlinal division within a differentiating tracheid after it exits from the cambial zone. If this interpretation is correct, the phenomenon is highly unusual but in part serves to explain the disorganized radial files.

\section{Silicisilvaxylon gen. nov.}

Type. - Silicisilvaxylon imprimicrystallus gen. et sp. nov.

Diagnosis. - In cross section, pycnoxylic low to medium density secondary xylem, uniseriate and less frequently bi- and multi-seriate rays, tracheid radial files usually well organized, resinous tracheids if at all present localized to zones where tracheid radial diameter is relatively small, axial parenchyma absent; in radial walls, long chains of uniseriate bordered pits contacting and of oblate outline or rounded and well spaced, always supplemented with bi-seriate pitting in alternate arrangement with pits either contacting and angular or spaced and rounded, cross-field pitting taxodioid/cupressoid sometimes podocarpioid/dacrydioid, almost invariably two large pits per cross-field arranged in a single horizontal row; in tangential section infrequent half- to full-sized bordered pits in scattered roughly uniseriate arrangement, rarely contacting and oblate, rays generally short, uniseriate, also combinations of uni-, bi- and tri-seriate, ray cells usually thin-walled homocellular rarely heterocellular with thick-walled terminal cells.

Etymology. - L. silicis to denote the flint-hardness of the permineralized woods in PEFO logs, L. silva for forest, L. xylon for wood.

Occurrence. - The type specimen and many additional large-diameter petrified logs reside within the Jim Camp Wash bed in the Sonsela Member of the Chinle Formation (minimum age $210 \mathrm{Ma}$, Riggs et al. 2003) just above the Rainbow Forest bed, in the same horizon where most petrified logs in Crystal Forest occur (Parker 2006, Savidge \& Ash 2006).

Remarks. - Silicisilvaxylon n. gen. tracheidoxyls are readily distinguished because, although uniseriate rays dominate the secondary xylem, bi- and tri-seriate rays are also present. In addition, two large-diameter pits per cross-field exist in a xylem having a combination of uni- and bi-seriate bordered pitting in the radial walls.

\section{Silicisilvaxylon imprimicrystallus gen. et sp. nov.} Figure 5

Holotype. - This specimen resides in the Crystal Forest region of Petrified Forest National Park, and its exact locality can be obtained upon request. Catalog numbers for thinsection holotype slides are PEFO 34811 (cross section), PEFO 34812 (radial section), and PEFO 34813 (tangential section), and those slides are stored in the Collections Department of Petrified Forest National Park.

Figure 4. Chinleoxylon knowltonii nov. gen. nov. sp., specimen USNM 30862. • A-C - cross section USNM 30862a \#76, disorganized medium-density xylem with moderately thick-walled tracheids and uniseriate rays, $\mathrm{C}$ showing an example (arrows) of how a radial file of tracheids changes into two then reverts to one in the following tier. $\bullet$ D-H - radial section \#77, showing bordered pits (D-G), H showing small taxodioid cross-field pits. $\bullet$ I-N - tangential section \#78, showing rays $(\mathrm{I}, \mathrm{J})$, bordered pits $(\mathrm{K}-\mathrm{M})$ and axial parenchyma cells $(\mathrm{N})$. 

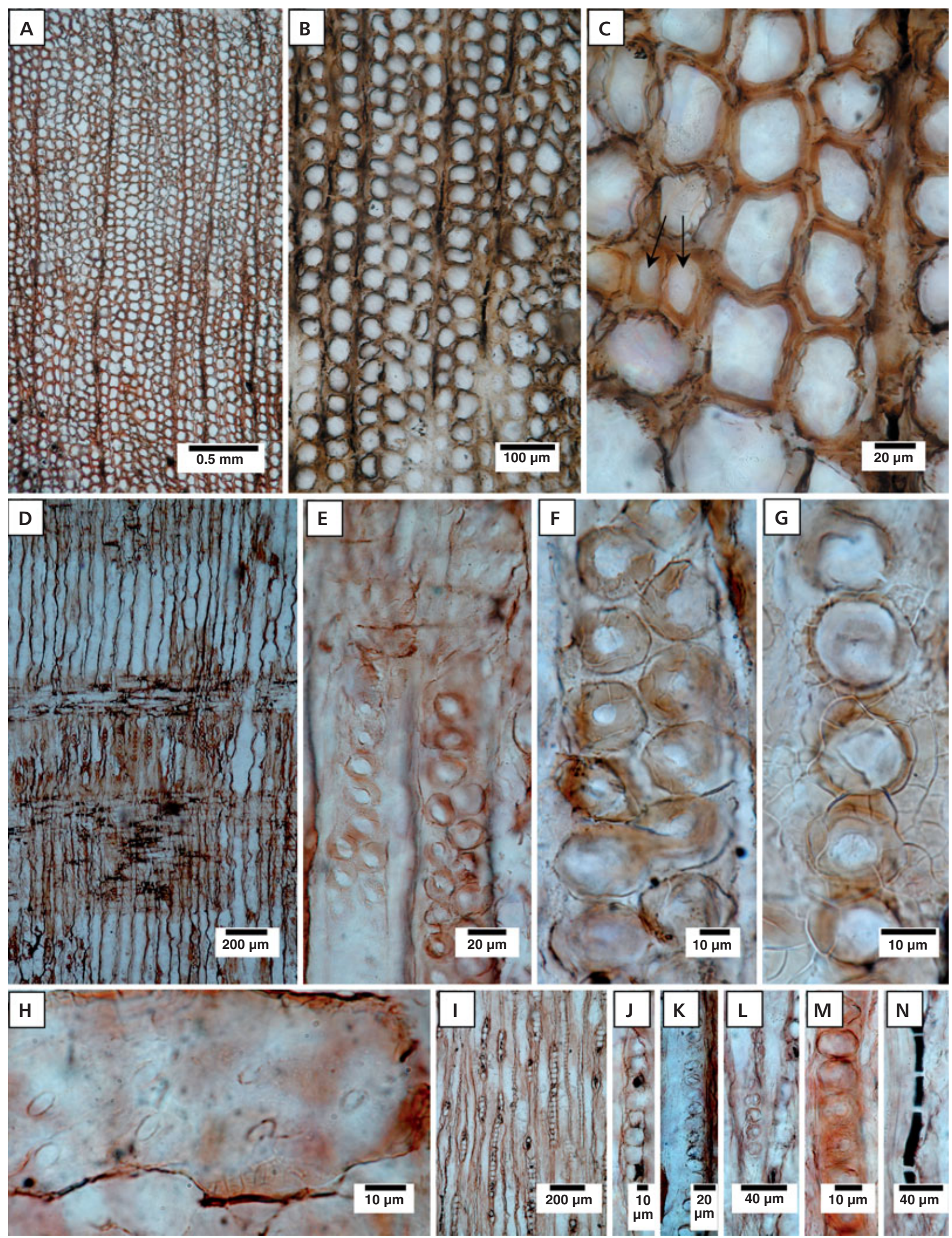
Diagnosis. - Secondary xylem anatomy conforms to features diagnostic of genus Silicisilvaxylon; in cross section radial files not well organized, tracheids angular to slightly rounded, lumens rounded, tracheid diameters to $60 \mu \mathrm{m}$ radial, $45 \mu \mathrm{m}$ tangential, intercellular spaces common but small, secondary walls 5-7 $\mu \mathrm{m}$ across; in radial section, bordered pits variable in placement and size (12-22 $\mu \mathrm{m}$, $5 \mu \mathrm{m}$ apertures) commonly mixed uniseriate/bi-seriate, partially angular in outline and both alternately and oppositely arranged where bi-seriate, circular to oblate within uniseriate chains, cross-field pitting two conspicuously large taxodioid $(\sim 12 \mu \mathrm{m}, 6-7 \mu \mathrm{m}$ aperture $)$ or cupressoid $(\sim 13 \mu \mathrm{m}, 6 \mu \mathrm{m}$ slit-like aperture) oculipores sometimes also presenting as podocarpioid and/or dacrydioid pits; in tangential section, rays short, usually $8-10$ cells but ranging from 1 to 18 , many rays fusiform shaped and partially bi- or tri-seriate appearing as incipient horizontal resin canals, most rays homocellular large diameter thin-walled cells (15-20 $\mu \mathrm{m}$ axial, 30-40 $\mu \mathrm{m}$ tangential) with only moderately thickened walls, ray cells oblate, circular or flattened, heterocellular rays possess smaller diameter (25-30 $\mu \mathrm{m}$ axial, 16-20 $\mu \mathrm{m}$ tangential) terminal cells with secondarily thickened $(5 \mu \mathrm{m})$ walls, the same also occasionally found within the ray.

Etymology. - L. imprimis to designate the first randomly selected log examined in this study, L. crystallus for crystal, because the fossil occurs in the Crystal Forest of Petrified Forest National Park.

Remarks. - This fossil is moderately well preserved, and its large pair of cross-field pits, partially bi- to tri-seriate rays having the shape of incipient resin canals, resinous tracheids and variable bordered-pit features including both angular alternating and opposite pitting when in bi-seriate arrangement set it apart from other known species in PEFO.

\section{Silicisilvaxylon secundacrystallus gen. et sp. nov.} Figure 6

Holotype. - This specimen resides in the Crystal Forest region of Petrified Forest National Park, and its exact locality can be obtained upon request. Catalog numbers for thinsection holotype slides are PEFO 34814 (cross section), PEFO 34815 (radial section), and PEFO 34816 (tangential section), and those slides are stored in the Collections Department of Petrified Forest National Park.

Diagnosis. - Secondary xylem anatomy conforms to features diagnostic of genus Silicisilvaxylon; in cross section radial files not well organized, tracheids angular to slightly rounded, lumens rounded, tracheid diameters to $60 \mu \mathrm{m}$ radial, $60 \mu \mathrm{m}$ tangential but usually smaller, intercellular spaces common, slender $(4-7 \mu \mathrm{m})$ secondary walls; in radial section, bordered pits of varied diameter (14-21 $\mu \mathrm{m}$, 3-6 $\mu \mathrm{m}$ apertures), uniseriate and bi-seriate, circular to oblate within long uniseriate chains, if bi-seriate both alternately and oppositely arranged, rounded or oblate, cross-field pitting two large ( 14 $\mu \mathrm{m}, 5-7 \mu \mathrm{m}$ aperture) taxodioid oculipores sometimes presenting as podocarpioid/ dacrydioid pits; in tangential section, rays generally medium length, 10-14 cells high but ranging from 1 to 25 cells, many rays partially bi-seriate, most rays homocellular, cells largediameter (15-20 $\mu \mathrm{m}$ tangential) thin-walled rounded or slightly elliptical, heterocellular rays with cells spaced $\sim 10 \mu \mathrm{m}$, long chains of half-sized $(8-10 \mu \mathrm{m})$ bordered pits in tangential walls.

Etymology. - L. secunda to designate the second randomly selected log examined in this study, L. crystallus for crystal, because the fossil occurs in the PEFO Crystal Forest.

Remarks. - This wood is moderately well preserved and its cross-field pitting, numerous uniseriate and some bi-seriate rays, and character of bordered pits in both radial and trangential walls, in association with its other secondary xylem features, set it apart. Silicisilvaxylon secundacrystallus gen. et sp. nov. is distinct from Silicisilvaxylon imprimicrystallus gen. et sp. nov. in displaying generally smaller cellular features, having taller rays and none with the fusiform shape of incipient resin canals, having few if any resinous tracheids, only rarely displaying angular bordered pits when in bi-seriate arrangement, and having long chains of uniseriate bordered pits in tracheid tangential walls.

\section{Crystalloxylon gen. nov.}

Type. - Crystalloxylon imprimicrystallus gen. et sp. nov.

Diagnosis. - In cross section, pycnoxylic secondary xylem comprising large tracheids of medium density, unise-

Figure 5. Silicisilvaxylon imprimicrystallus nov. gen. nov. sp. $\bullet$ A - the top end of the sampled specimen. $\bullet$ B-D - cross section PEFO 34811 , well organized medium-density xylem with moderately thick-walled tracheids, uniseriate rays, and scattered resinous tracheids associated with growth interruptions (arrowed in B and C), with the arrowhead in C pointing to a tri-seriate ray. $\bullet E-I-$ radial section PEFO 34812, showing bordered pits (E-H) with two examples of opposite bi-seriate pitting shown in $\mathrm{G}$ (one arrowed) and the large taxodioid/cupressoid cross-field pits evident in $\mathrm{H}$ and I. $\bullet \mathrm{J}, \mathrm{K}-$ tangential section PEFO 34813, showing short rays and evidence for incipient horizontal resin canals (one arrowed in K). 

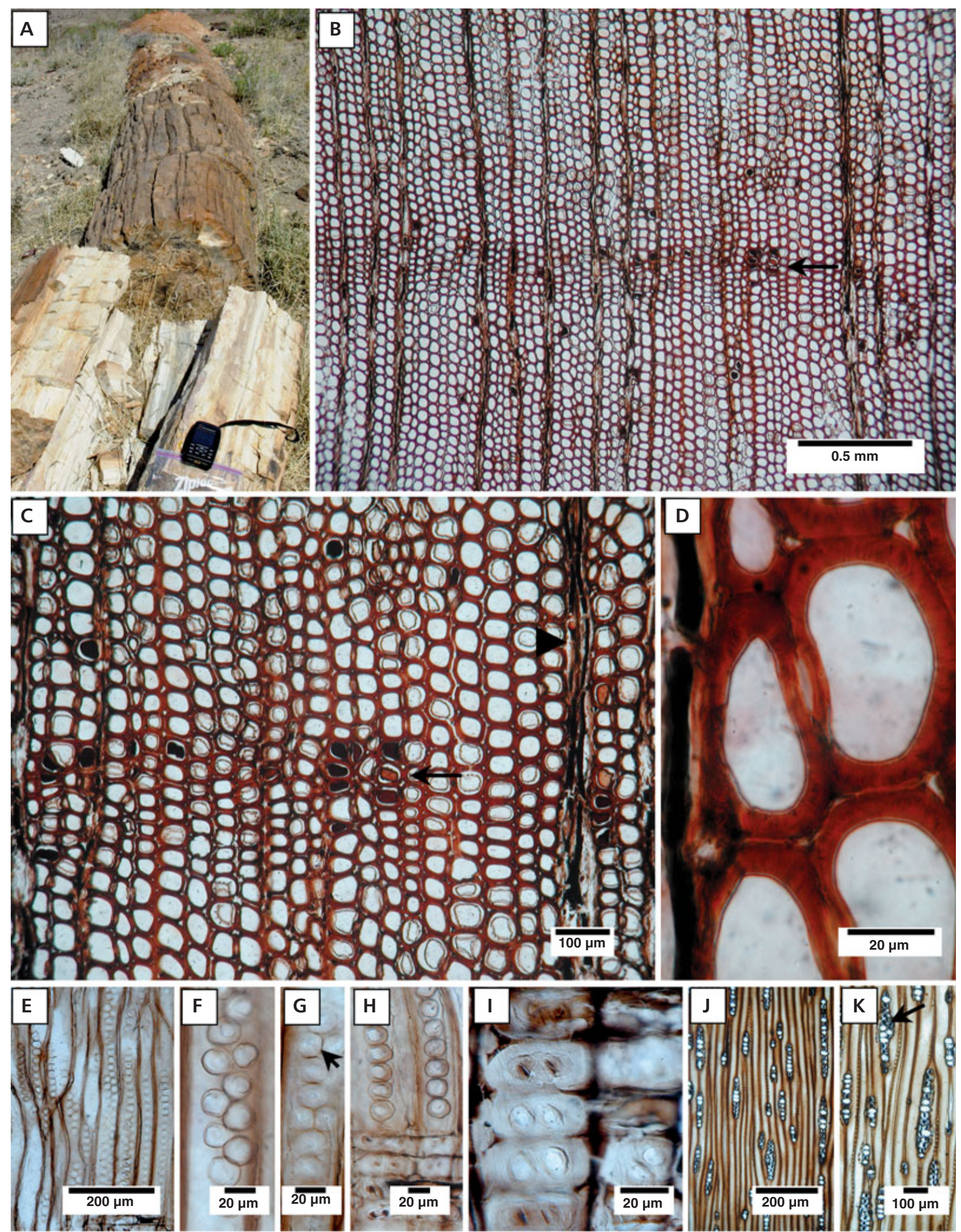
riate rays spaced well apart, tracheid radial files generally well organized, intercellular spaces common, tracheids adjoining rays commonly much longer in radial than tangential dimension, narrow diameter canals penetrating tracheid secondary walls to link with oculipores in ray cell walls; in radial section, strikingly abundant bi-seriate sometimes partially tri-seriate pitting in alternate arrangement with pits usually rounded and spaced apart, uniseriate bordered pits when present also rounded and mostly well spaced, cross-field pitting primarily taxodioid sometimes cupressoid, two to three pits per cross-field arranged in a single horizontal row; in tangential section, rays uniseriate, occasionally partially bi-seriate, mixed short and long, thin-walled homocellular, ray cells large, upright, elliptical, tangential wall bordered pits rarely seen, when present uniseriate and similar diameter to those in the radial walls.

Etymology. - L. crystallos for rock crystal, L. xylon for wood.

Occurrence. - The type specimen and many additional large-diameter petrified logs are set within the Jim Camp Wash bed in the Sonsela Member of the Chinle Formation (minimum age $210 \mathrm{Ma}$, Riggs et al. 2003) just above the Rainbow Forest bed, in the same horizon where most petrified logs in Crystal Forest occur (Parker 2006, Savidge \& Ash 2006).

Discussion. - Crystalloxylon gen. nov. tracheidoxyls are readily distinguished by their abundant display of mostly bi-seriate radial wall bordered pits, essentially none being present in tangential walls, these exhibiting a mixture of short and long well-organized uniseriate rays. Additional useful diagnostic features reside in the common occurrence in cross section of 'squashed' tracheids associated with ray cells and of secondary-wall canals, rather than half-bordered pits, connecting tracheid lumens to simple pits in adjoining thin-walled ray cells.

\section{Crystalloxylon imprimicrystallus gen. et sp. nov.} Figure 7

Holotype. - This specimen resides in the Crystal Forest region of Petrified Forest National Park, and its exact locality can be obtained upon request by approved persons. Catalog numbers for thin-section holotype slides are PEFO 34817 (cross section), PEFO 34818 (radial section), and PEFO 34819 (tangential section), and those slides are stored in the Collections Department of Petrified Forest National Park.

Diagnosis. - Secondary xylem anatomy conforms to features diagnostic of genus Crystalloxylon; in cross section radial files well organized, tracheids mostly rounded, large intercellular spaces, lumens rounded, tracheid diameters to $75 \mu \mathrm{m}$ radial, $60 \mu \mathrm{m}$ tangential, thick $(7-8 \mu \mathrm{m})$ secondary walls, when adjoining a ray cell tracheids present deformed ('squashed') appearance with radial diameter often $>5 \times$ tangential diameter, bi-seriate pitting obvious in radial walls, canals rather than pits traverse tracheid secondary walls contacting ray cells; in radial section, both uniseriate and bi-seriate barely contacting bordered pits of similar diameter (18-24 $\mu \mathrm{m}, 3-5 \mu \mathrm{m}$ apertures), rounded or oblate in outline, alternately arranged where bi-seriate, circular to oblate within short uniseriate chains, cross-field pitting three to six small $(\sim 5 \mu \mathrm{m})$ elliptical taxodioid oculipores sometimes also presenting as oopores; in tangential section, rays of varied lengths, 2-40 cells high, rarely partially bi-seriate, homocellular, small diameter (10-20 $\mu \mathrm{m}$ tangential, 25-40 $\mu \mathrm{m}$ axial) thin-walled elliptical cells.

Etymology. - L. imprimis to designate the first such log examined in this study, L. crystallus for crystal, because the fossil occurs in the Crystal Forest of Petrified Forest National Park.

Discussion. - This fossil is moderately well preserved, and its conspicuous alternating bi-seriate but rounded bordered pits and absence of half-bordered pits (evidently substituted by narrow canals), in association with additional diagnostic features of it secondary xylem, amply distinguish it.

\section{Arboramosa Savidge \& Ash, 2006}

Type. - Arboramosa semicircumtrachea Savidge \& Ash, 2006.

Emended diagnosis. - Secondary xylem surface with fusiform-shaped cavities parallel to main stem axis in regular

Figure 6. Silicisilvaxylon secundacrystallus nov. gen. nov. sp. $・$ A - the top end of the sampled specimen. $\bullet$ B-E - cross section PEFO 34814 , well organized low-density xylem with moderately thick-walled relatively small-diameter tracheids and uniseriate rays, intercellular spaces and tangential wall pitting clearly shown in D and radial wall pitting (one arrowed) in E. $\bullet$ F-J - radial section PEFO 34815, showing cupressoid/ taxodioid cross-field pits (F, J), uniseriate $(\mathrm{H})$ and bi-seriate $(\mathrm{G}, \mathrm{I})$ bordered pits. $\bullet \mathrm{K}, \mathrm{L}-$ tangential section PEFO 34816, showing short to medium-length rays (K) and separations (L, one arrowed) between ray cells. 

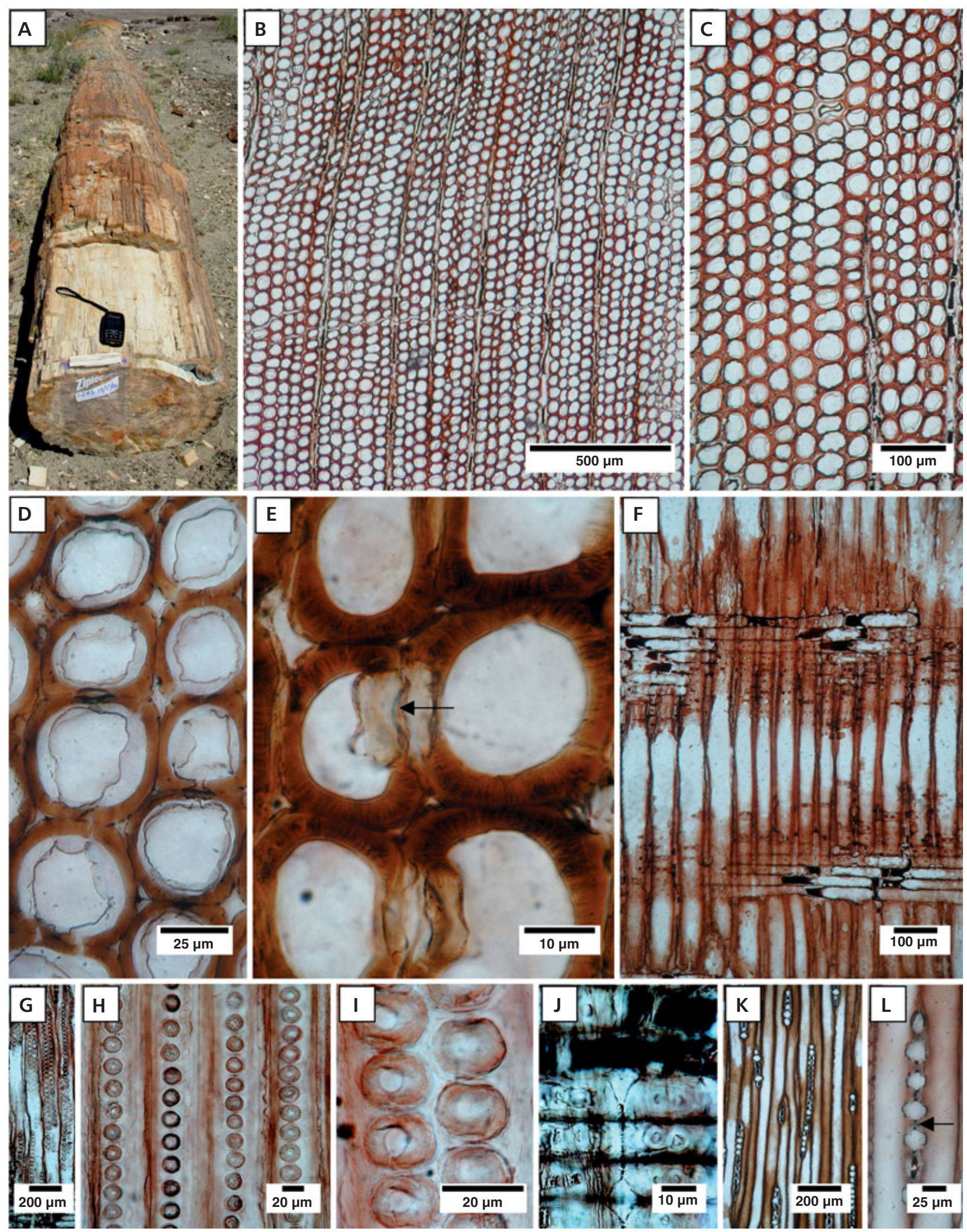
spiralled arrangement; lateral branch stubs having small diameter pith, stubs or branches egress from fusiformshaped cavities. Secondary xylem tracheids round to semi-round in transverse section, having bordered pits on all wall surfaces, mixed but mostly abietinian pitting, axial parenchyma present but scarce; xylem pycnoxylic, composed of thin-walled homogeneous uniseriate ray cells, oculipore cross-field pittting; other parenchyma wanting.

Discussion. - This revision records the small diameter of the pith, a feature that was uncertain when the type was first described (Savidge \& Ash 2006). A longitudinal section through a branch stub revealed a pith less than on millimetre in diameter, indicating that the genus Arboramosa is within Pinophyta.

\section{Protopiceoxylon novum Savidge, 2006}

Holotype. - This specimen resides in the Blue Mesa region of Petrified Forest National Park, locality PFP 118. Thin-section slides are filed under catalog number PEFO 35349 (3 slides, cross, radial and tangential sections) and stored in the Collections Department of Petrified Forest National Park.

Emended diagnosis. - See remarks.

Remarks. - Resin canals within the secondary xylem were the key feature underlying the proposal of Protopiceoxylon novum as a new morphotaxon (Savidge 2006), but it subsequently became apparent that similar resin canal-like structures occur in other woods as artifacts of mineralization. This fossil is not particularly well preserved and, therefore, the question of whether the objects previously described are in fact resin canals cannot be confidently answered. The original diagnosis is considered incorrect and the taxon hereby transferred to nomina dubiu.

\section{General discussion}

Fossilized parts of whole plants are named and described within the rules and recommendations of the International Code of Botanical Nomenclature (Greuter et al. 1999), where formal synonymy and operation of the priority prin- ciple are constrained within the framework and boundaries of named morphotaxa and their diagnoses (Code Article 11.7). However, qualitative definition of morphotaxon categories is not regulated by the Code, rather left for investigators to resolve. Consequently, upon re-examination of an earlier named specimen, if features are found which were not mentioned in the original diagnosis or its protologue, the investigator(s) may propose an emended diagnosis or, alternatively, assign the specimen to another pre-existing or a new taxon.

When investigating an unnamed fossil wood, although it may exhibit all anatomical features given for an earlier designated type, the Code does not strictly require that the specimen be regarded on that basis as an isotype of one having nomenclatural priority. If it can be shown that the unknown contains additional, distinguishing anatomical features not mentioned in the diagnosis of the type having nomenclatural priority, those additional features may be sufficient justification for the unknown being proposed as a new taxon. To quote the Code (Greuter et al. 1999): "32.2. A diagnosis of a taxon is a statement of that which in the opinion of its author distinguishes the taxon from others" and "strict synonymy and therefore priority only operates among morphotaxa of the same kind."

In the preamble to the Code, Greuter et al. (1999) state: " 9 . The only proper reasons for changing a name are either a more profound knowledge of the facts resulting from adequate taxonomic study or the necessity of giving up a nomenclature that is contrary to the rules." In the case of Araucarioxylon arizonicum Knowlton, 1889, both concerns apply. The present investigation revealed anatomical heterogeneity among the three Araucarioxylon arizonicum Knowlton, 1889 syntypes, and each has therefore been treated as a separate morphotaxon. In addition, the genus Araucarioxylon Kraus, 1870 is nomen superfluum, because this artifical genus was created arbitrarily from other, earlier named, genera (Seward 1917, Philippe 1993, Bamford \& Phillipe 2001).

At the heart of reassigning the three Araucarioxylon arizonicum Knowlton, 1889 syntypes to new genera is an old scientific controversy, sometimes described colloquially as 'lumping' versus 'splitting', i.e. the subjective tendencies among researchers when presented with sets of real anatomical differences, such as those listed in Table 1, to assume that they either are, or are not, sufficient to merit assignment to distinct morphotaxa. Support for 'lumping' came with the assumptions that pycnoxylic woods of Late

Figure 7. Crystalloxylon imprimicrystallus nov. gen. nov. sp. $\bullet$ A - the butt-end of the sampled specimen. $\bullet$ B-D - cross section PEFO 34817 , well organized medium-density xylem with evidence for growth interruptions (two arrowed in B), moderately thick-walled large-diameter tracheids and uniseriate rays, D showing an example of a 'squashed' tracheid adjoining a ray, intercellular spaces and narrow diameter canals (arrows) linking with oculipores (arrowheads). $\bullet \mathrm{E}, \mathrm{F}$ - tangential section PEFO 34819, showing well organized short to long uniseriate rays. • G-J - radial section PEFO 34818 , showing conspicuous bi-seriate pitting $(\mathrm{G}-\mathrm{I})$ and taxodioid/cupressoid cross-field pits (J). 


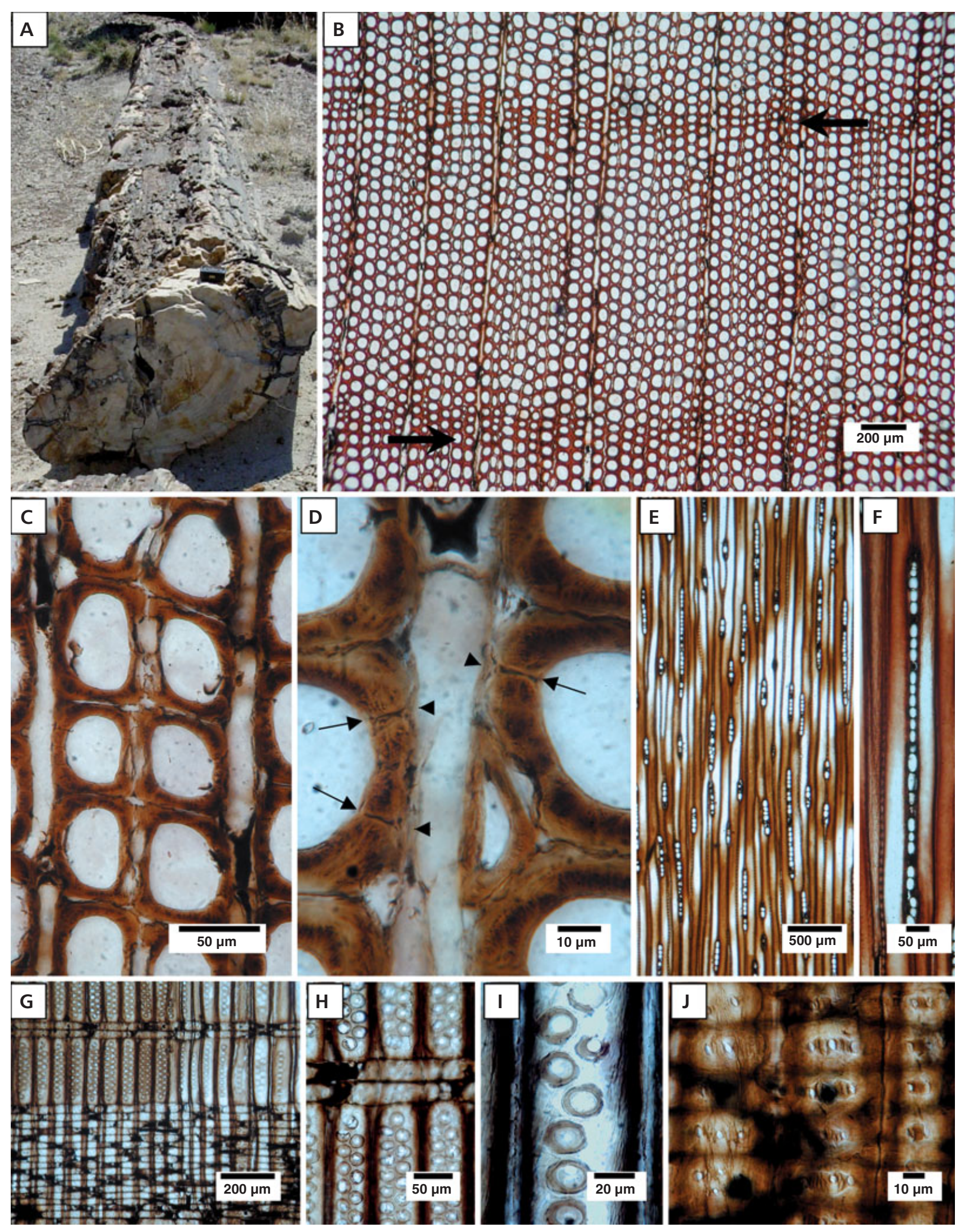


Palaeozoic and Mesozoic are highly conserved and variable (Bailey 1933). However, the origin of such assumptions was based on superficial and eclectic low-magnification analyses of only a few of the many secondary xylem features which might otherwise have been investigated in higher magnification more comprehensive studies. From the 'splitting' perspective, it deserves consideration that there are numerous examples in living tree species of two woods being anatomically indistinguishable although morphological differences nevertheless justify typing the trees as distinct species. The converse, however, does not apply. As a general rule, when the full set of anatomical features in woods from the same organ (e.g., bole, branch, twig, root) are compared and found to be distinct, it can be concluded, based on investigations with extant species, that the outward organs of the plants producing those woods would qualify as different taxa (Phillips 1948, Panshin \& de Zeeuw 1980, Hoadley 1990).

Wood is unquestionably a natural data storage system (Bannan \& Bayly 1956, Creber 1977), and the anatomical features stored in each wood manifest gene expression and metabolism that occurred in living cells within and on the margins of the vascular cambium, each woody element achieving its final phenotype through interactions between the somatic genome of the whole plant and its environment (Savidge 1996, 2000, 2001). Thus, fossil wood systematics could resolve morphotaxa more effectively if it extended into acquisition of intensive data about minute features to enable broader comparison of entires sets of microfeatures among taxa. General adoption of more anatomically rigorous tracheidoxyl classification would undoubtedly lead to many formerly diagnosed taxa being considered for revision. However, an obvious corollary to this suggestion is that permineralized specimens must be sufficiently well preserved to enable high magnification resolution of their minute features.

Tracheidoxyl investigators have placed considerable emphasis on various bordered-pit characteristics; however, knowledge about bordered-pit formation and its regulation by intrinsic and extrinsic factors remains a neglected topic in plant physiology. From the very limited research done, evidence has emerged that so-called "abietinoid" conifers are in fact competent to produce multi-seriate, closely packed and angular bordered pits (Savidge 1983) and also alternating bi-seriate pits (Leitch \& Savidge 1995), raising the question of why Pinaceae so infrequently exhibit the so-called "araucaroid" phenotype. The specimens investigated in this study reveal that mixed-pitting phenotypes extend to Late Triassic trees, as exhibited in Arboramosa semicircumtrachea, Chinleoxylon knowltonii, Crystalloxylon imprimicrystallus, Protocupressoxylon arizonicum, Ginkgoxylpropinquus hewardii, Silicisilvaxylon imprimicrystallus, and S. secundacrystallus. Mixed pitting phenotypes may be an indication that those trees were evolving toward extant Araucariaceae and, conversely, the absence of mixed pitting in Pullisilvaxylon arizonicum and $P$. daughertii indicate evolution toward the abietinoid expression so commonly found in Modern conifers.

The literature frequently refers to araucarian pits as being compressed or flattened, angular, polygonal or hexagonal. However, the notion that araucarian pitting when bi-, tri- or multi-seriate is invariably angular is clearly wrong, because rounded alternating pits together with rounded uniseriate or isolated pits occur in Araucaria woods that also display angular pits (Bailey 1933, R. Savidge, unpublished data). Some have assumed that oblate or angular pit outlines when present are due to mutual contacting forces (e.g., Pool 1929), but with present knowledge terms such as 'compressed' and 'flattened' are assumptive. On the other hand, there is evidence that an organelle, evidently derived from the vacuole, is involved in bordered-pit formation (Savidge 2000, 2003), and conceivably the oblate and angular phenotypes arise in response to organelles pressing their membranes against one another at the beginning of the bordered-pit formation process.

\section{Conclusions}

There has been widespread and less than rigorous application of the Araucarioxylon type to permineralized woods, but for nomenclatural reasons the genus is superfluous and therefore illegitimate. Moreover, the original wood anatomy requirements for inclusion in type Araucarioxylon were subsequently both liberally and non-uniformly interpreted, such that morphotaxa assigned to that genus no longer have much if any systematic value. In relation to Araucarioxylon arizonicum Knowlton, 1889, each of the three original syntypes in fact is anatomically distinct. Recognizing this diversity and rejecting the Araucarioxylon type on the basis of incorrect nomenclature, only one of those three specimens is retained as the lectotype of Pullisilvaxylon arizonicum (Knowlton) gen. et comb. nov.

The evidence supports the conclusion that Late Triassic petrified logs in the region of Petrified Forest National Park represent a broad diversity of species, many of which probably remain to be discovered. A key to aid in distinguishing named morphotaxa is provided in Appendix, but it undoubtedly will undergo extensive revision as new taxa are described.

The naming of each 'species' or morphotaxon can never be regarded as an absolute or final determination, because taxonomy is merely imposition of informed scientific opinion upon the diversity existing in the biological world, the aims being to achieve ordered, objective and mutually agreeable ways of analysis and communication. The International Code of Botanical Nomenclature wisely avoids attempting to specify criteria for speciation, thus en- 
abling revision and refinement of systematic classification. This consideration has three important implications for the future of tracheidoxyl taxonomy: i) Known morphotaxa may be re-examined and emended based on new findings; ii) Eventually, with ever greater attention to detail, uniform anatomical criteria for describing and comparing all tracheidoxyls will emerge; iii) Known morphotaxa not amenable to providing additional information on their anatomies, because of low quality figures in publications, poor preservation or non-availability of the original specimen, can be nomenclaturally conserved (Article 14.2 of the Code) but may be disregarded in future research.

\section{Acknowledgements}

My thanks to Sidney Ash for encouraging me to undertake this research and sharing information he had on the specimens in the Smithsonian Institution, and making many helpful suggestions for improving the penultimate draft of this paper. I am grateful to Jonathan Wingerath of the Smithsonian Institution for facilitating a loan of the type material and making dimensional measurements on two of the type specimens. Marc Philippe provided very helpful perspective on Araucarioxylon systematics, and Christopher J. Cleal, Ronny Rössler, Josef Pšenička, co-editor Jakub Sakala and two anonymous reviewers provided many useful comments on the manuscript particularly in relation to satisfying ICBN rules. Elisabeth Wheeler provided critical commentary on resin canals in relation to Protopiceoxylon novum. Anne Savidge translated the French in Kraus (1870). Karen Beppler-Dorn, Chief of Resource Management at Petrified Forest National Park, authorized research on the permineralized logs within Petrified Forest National Park. Ancel Murphy and Calvin Nash of UNB prepared thin sections.

\section{References}

ANDREWS, H.N. 1970. Index of generic names of fossil plants, 1820-1965. Geological Survey Bulletin 1300.

AsH, S.R. 1972. The search for plant fossils in the Chinle Formation, 23-43. In BREED, W.J. \& BREED, C.S. (eds) Investigations in the Triassic Chinle Formation. Museum Northern Arizona Bulletin 47.

ASH, S.R. 1985. A short thick cycad stem from the Upper Triassic of Petrified Forest National Park, Arizona, and vicinity. Museum of Northern Arizona Bulletin 54, 17-32.

AsH, S.R. 1992. The Black Forest bed, a distinctive unit in the Upper Triassic Chinle Formation, Northeastern Arizona. Journal of the Arizona-Nevada Academy of Science 24-25, 59-73.

Ash, S.R. \& CREBER, G. 2000. The Late Triassic Araucarioxylon arizonicum trees of the Petrified Forest National Park, Arizona, USA. Palaeontology 43, 15-28.

ASH, S.R. \& SAVIDGE, R.A. 2004. The bark of the Late Triassic
Araucarioxylon arizonicum tree from Petrified Forest National Park, Arizona. IAWA Journal 25, 349-368.

BAILEY, I.W. 1933. The cambium and its derivative tissues VII. Problems in identifying the wood of Mesozoic Coniferae. Annals of Botany 47, 145-157.

BAMFORD, M.K. \& PHILIPPE, M. 2001. Jurassic - Early Cretaceous Gondwanan homoxylous woods: a nomenclatural revision of the genera with taxonomic notes. Review of $\mathrm{Pa}$ laeobotany and Palynology 113,287-297. '

BANNAN, M.W. \& BAYLY, I.J. 1956. Cell size and survival in conifer cambium. Canadian Journal of Botany 34, 769-776.

BAREFOOT, A.C. \& HANKINS, F.W. 1982. Identification of Modern and Tertiary woods. 189 pp. Clarendon Press, Oxford.

CONRAD, E. 1910. Beiträge zur Morphologie und Anatomie von Agatis (Dammara) brownii. PhD Dissertation, University of Kiel.

CREBER, G.T. 1972. Gymnospermous woods from the Kimmeridgian of East Sutherland and from the Sandringham Sands of Norfolk. Palaeontology 15, 665-661.

CREBER, G.T. 1977. Tree rings: a natural data-storage system. Biological Reviews 52, 349-383.

DARRAH, W.C. 1939. Textbook of paleobotany. 441 pp. Appleton-Century, New York, London.

DAUGHERTY, L.H. 1934. Schilderia adamanica - a new fossil wood from the petrified forests of Arizona. Botanical $\mathrm{Ga}$ zette 96, 363-366.

DAUGHERTY, L.H. 1941. The Upper Triassic flora of Arizona. Carnegie Institute of Washington Publication 526, 1-108.

DAWSON, J.W. 1871. The fossil plants of the Devonian and upper Silurian formations of Canada. 92 pp. Geological Survey of Canada, Ottawa, Dawson Brothers, Montreal.

ECKHOLD, W. 1922. Die Hoftüpfel bei rezenten und fossilen Koniferin. Jahrbuch der preussischen geologischen Landesantalt 42, 472-505.

ENDLICHER, S.L. 1847. Conspectus coniferarum fossilium, 1-52. In ENDLICHER, S.L. (ed.) Synopsis Coniferarum. Scheitlin and Zollikofer, St.-Gall.

GERRY, E. 1910. The distribution of the "bars of Sanio" in the Coniferales. Annals of Botany 24, 119-124.

GÖPPERT, H.R. 1850. Monographie der fossilen Coniferen. 286 pp. Natuurkundige Verhandelingen van de Hollandse maatschappij der Wetenschappen te Harlem, $2^{\mathrm{e}}$ verzam, $6^{\mathrm{e}}$ deel. Arnz and Company, Leiden.

Gothan, W. 1905. Zur Anatomie lebender und fossiler Gymnosperm-Hölzer. Abh. D. Königlich Preussischen Geologischen Landesanstalt und Bergakademie. Neue Folge 44, $1-108$.

GOULD, R.E. 1971. Lyssoxylon grigsbyi, a cycad trunk from the Upper Triassic of Arizona and New Mexico. American Journal of Botany 58, 239-248.

Greuter, W., MCNEILl, J., BARRIER, F.R., BURdET, H.-M., Demoulin, V., Filgueiras, T.S., Nicolson, D.H., 
Silva, P.C., Skog, J.E., Trehane, P., Turland, N.J. \& HAWKSWORTH, D.L. 1999. International code of botanical nomenclature (St. Louis Code). Regnum vegetabile. 138 pp. Koeltz Scientific Books, Königstein.

HARTIG, T. 1848. Beiträge zur Geschichte der Pflanzen und zur Kenntnis der norddeutschen Braunkohlen-Flora. Botanisches Zeitung 6, 122-128, 137-141, 166-172, 185-190.

HOADLEY, R.B. 1990. Identifying wood: accurate results with simple tools. 240 pp. Taunton, Newtown, CT, USA.

HoLDEN, R. 1913. Contributions to the anatomy of Mesozoic conifers. No. 1. Jurassic coniferous woods from Yorkshire. Annals of Botany 27, 533-545 + plates 39, 40.

JEFFREY, E.C. 1910. A new araucarian genus from the Triassic. Boston Society of Natural History Proceedings, 34, 325-332.

JEFFREY, E.C. 1911. The affinities of Geinitzia gracillima. Botanical Gazette 51, 21-27.

JEFFREY, E.C. 1913. The history, comparative anatomy and evolution of the Araucarioxylon type. American Academy of Arts and Sciences Proceedings 48, 531-571.

KnOWLTON, F.H. 1889. New species of fossil wood (Araucarioxylon arizonicum) from Arizona and New Mexico. U.S. National Museum Proceedings 1888, 11, 1-4.

KNOWLTON, F.H. 1890. A revision of the genus Araucarioxylon of Kraus, with compiled descriptions and partial synonymy of the species. U.S. National Museum Proceedings 1889, 12, 601-617.

KnOwlton, F.H. 1913. Fossil forests of Arizona. American Forestry 19, 209-218.

KnOwLtON, F.H. 1919. A catalogue of the Mesozoic and Cenozoic plants of North America. United States Geological Survey Bulletin 696, 1-815.

KraUs, G. 1870. Bois fossiles de conifères, Pt. 2, 363-385. In SCHIMPER, W.P. (ed.) Traité de Paléontologie Végétale, J.B. Baillière et fils, Strasbourg.

KRÄUSEL, R. 1949. Die fossilen Koniferenhölzer (unter Ausschluss von Araucarioxylon Kraus). Palaeontographica, Abt. B, Paläophytologie 62, 185-275.

LEITCH, M.A. \& SAVIDGE, R.A. 1995. Evidence for auxin regulation of bordered-pit positioning during tracheid diferentiation in Larix laricina. IAWA Journal 16, 289-297.

Morgenroth, E. 1883. Die fossilen Pflanzenreste im Dilluvium der Umgebung von Kamenz in Sachsen. 50 pp. Tausch \& Grosse, Halle.

PANSHIN, A.J. \& DE ZEEUW, C. 1980. Textbook of wood technology: structure, identification, properties, and uses of the commercial woods of the United States and Canada. $736 \mathrm{pp}$. McGraw-Hill, New York.

PARKER, W.G. 2006. The stratigraphic distribution of major fossil localities in Petrified Forest National Park, Arizona, 46-61. In PARKER, W.G., AsH, S.R. \& IRMIS, R.B. (eds) A century of research at Petrified Forest National Park: geology and paleontology. Museum of Northern Arizona Bulletin 62.

PHILIPPE, M. 1993. Nomenclature générique des trachéido- xyles fossils mésozoïques á champs araucarioïdes. Taxon 42, 74-80.

PHILIPPE, M. 1995. Bois fossiles du Jurassique de franchecomté (NE-France). Palaeontographica Abt. B 236, 45-103.

PHILLIPS, E.W.J. 1948. Identification of softwoods by their microscopic structure. Forest Products Research Bulletin 22, $1-56$.

PooL, J.W. 1929. On the anatomy of Araucarian wood. Recueil des travaux botaniques Neerlandais 25, 484-620.

Riggs, N.R., Ash, S.R., Barth, A.P., Gehrels, G.E. \& WoODEN, L.L. 2003. Isotopic age of the Black Forest Bed, Petrified Forest member, Chinle Formation, Arizona: an example of dating a continental sandstone. Geological Society of America Bulletin 115, 1315-1312.

SAVIDGE, R.A. 1983. The role of plant hormones in higher plant cellular differentiation. II. Experiments with the vascular cambium, and sclereid and tracheid differentiation in the pine, Pinus contorta. Histochemical Journal 15, 447-466.

SAVIDGE, R.A. 1993. Formation of annual rings in trees, 343-363. In RENSING, L. (ed.) Oscillations and morphogenesis. Marcel Dekker, New York.

SAVIDGE, R.A. 1996. Xylogenesis, genetic and environmental regulation - a review. IAWA Journal 17, 269-310.

SAVIDGE, R.A. 2000. Biochemistry of seasonal cambial growth and wood formation - an overview of the challenges, 1-30. In SAVIDGE, R.A., BARNETT, J.R. \& NAPIER, R. (eds) Cell and molecular biology of wood formation. BIOS Scientific, Oxford.

SAVIDGE, R.A. 2001. Intrinsic regulation of cambial growth. Journal of Plant Growth Regulation 20, 52-77.

SAVIDGE, R.A. 2003. Tree growth and wood quality, 1-29. In BARNETT, J.R. \& JERONIMIDIS, G. (eds) Wood quality and its biological basis. Blackwell and CRC Press, Oxford and Boca Raton, Florida, USA.

SAVIDGE, R.A. 2006. Xylotomic evidence for two new conifers and a ginkgo within the Late Triassic Chinle Formation of Petrified Forest National Park, Arizona, USA, 147-149. In PARKER, W.G., ASH, S.R. \& IRMIS, R.B. (eds) A century of research at Petrified Forest National Park: geology and paleontology. Museum of Northern Arizona Bulletin 62.

SAVIDGE, R.A. \& ASH, S.R. 2006. Arboramosa semicircumtrachea, an unusual Late Triassic tree in Petrified Forest National Park, Arizona, USA, 65-81. In PARKER, W.G., ASH, S.R. \& IRMIS, R.B. (eds) A century of research at Petrified Forest National Park: geology and paleontology. Museum of Northern Arizona Bulletin 62.

SAVIDGE, R.A. \& FÖRSTER, H. 1998. Seasonal activity of uridine 5'-diphosphoglucose: coniferyl alcohol glucosyltransferase in relation to cambial growth and dormancy in conifers. Canadian Journal of Botany 76, 486-493.

SCOTT, R.A. 1961. Fossil woods associated with uranium on the Colorado Plateau. Short Papers in the Geologic and 
Hydrologic Sciences. U.S. Geological Survey Professional Paper 424-B, B130-B132.

SEWARD, A.C. 1904. Catalogue of the Mesozoic plants in the Department of Geology The Jurassic flora II. Liassic and Oolitic floras of England. 192 pp. British Museum (Natural History), London.

SEWARD, A.C. 1917. Fossil plants, volume III, Pteridospermeae, Cycadofilices, Cordaitales, Cycadophyta. 656 pp. Cambridge University Press, reprinted by Hafner, New York and London.

SEWARD, A.C. 1919. Fossil Plants Vol. IV, Ginkgoales, Coniferales, Gnetales. 543 pp. Cambridge University Press, reprinted by Hafner, New York, London.

SINNOT, E.W. 1909. Paracedroxylon, a new type of araucarian wood. Rhodora 11, 165-173.

SOLMS-LAUBACH, H. GRAF ZU 1891. Fossil botany, being an introduction to palaeophytology from the standpoint of the botanist. 401 pp. Clarendon, Oxford.

STOPES, M.C. 1914. A new Araucarioxylon from New Zealand. Annals of Botany 28, 341-350.
SWAine, P.T. \& HeGEWALD, J.F.C. 1882. Information concerning some fossil trees in the United States National Museum. U.S. National Museum Proceedings 5, 1-3.

UNGER, F. 1850. Genera et Species Plantarum fossilium. 627 pp. Vienna.

WHIPPLE, A.W. 1856. Report of explorations for a railway route, near the thirty-fifth parallel of latitude, from the Mississippi River to the Pacific Ocean. U.S. $33^{\text {rd }}$ Congress, $1^{\text {st }}$ Session, Secretary of War Executive Document 129(3), $1-154$.

WITHAM, H. 1833. The internal structure of fossil vegetables, found in the Carboniferous and Oolitic deposits of Great Britain, described and illustrated. $84 \mathrm{pp}$. Adam and Charles Black, Edinburgh.

WoODY, D.T. 2006. Revised stratigraphy of the Lower Chinle Formation (Upper Triassic) of Petrified Forest National Park, 17-45. In PARKER, W.G., ASH, S.R. \& IRMIS, R.B. (eds) A century of research at Petrified Forest National Park: geology and paleontology. Museum of Northern Arizona Bulletin 62.

\section{Appendix - Key for diagnosing Late Triassic morphotaxa in southwestern USA based on anatomical features within secondary xylem of permineralized logs}

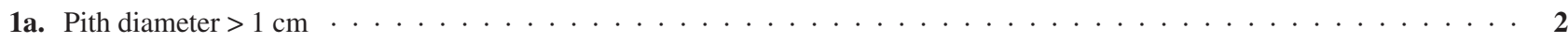

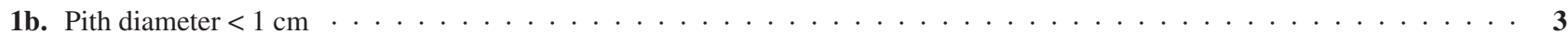

2a. Rays short (1-10 cells high)

Dadoxylon chaneyi Uniseriate rays; radial wall bordered pitting mixed uniseriate/bi-seriate, when bi-seriate hexagonal and alternate; tangential wall taxodioid oculipores present.

2b. Rays long

Lyssoxylon grigsbyi Both uni- and uni-/bi-seriate heterocellular rays comprising as many as 50 cells, also multi-seriate ( $\sim 12$ cells wide in the center) heterocellular fusiform rays, the latter housing internalized leaf traces; radial wall bordered pitting relatively small diameter, slit-like apertures, mostly bi- but also uni- and multi-seriate, hexagonal; relatively small diameter tracheids with $\mathrm{S}_{3}$ spiral bands, tyloses; axial parenchyma sparsely present.

2c. Pith radius much larger than secondary xylem radius

Charmorgia dijolli

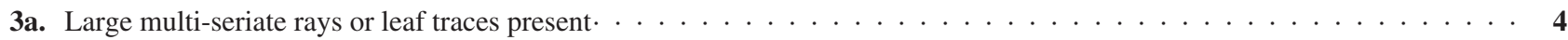

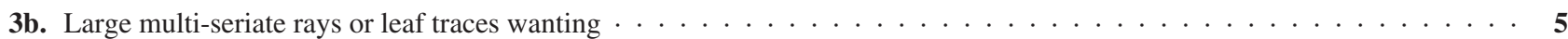

4a. Multi-seriate rays obvious without magnification

Schilderia adamanica Multi-seriate heterocellular herring-bone type rays 5-10 $\mathrm{mm}$ high, $0.3 \mathrm{~mm}$ wide, also very narrow uniseriate rays; radial wall bordered pitting uni- and bi-seriate, hexagonal and alternating when bi-seriate; axial parenchyma in small groupings and short tangential tiers in association with growth interruptions.

4b. Multi-seriate rays not obvious; leaf traces obvious Persistent branch and leaf traces common; short uniseriate rays; radial wall bordered pitting mixed uniseriate - bi-seriate, when bi-seriate hexagonal and alternate, tangential wall bordered pits half-size and uniseriate; scattered resinous tracheids. 
5a. In tangential section, bi-seriate rays common $\ldots \ldots \ldots \ldots$

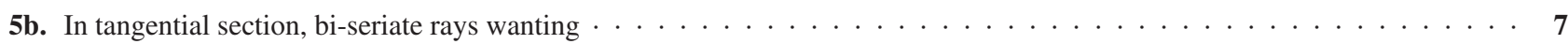

6a. In tangential section, short bi- and tri-seriate rays appear as incipient horizontal resin canals Silicisilvaxylon imprimicrystallus Closely spaced short homocellular occasionally heterocellular rays mostly uniseriate, also commonly bi-/tri-seriate and fusiform shaped in tangential section, appearing as incipient horizontal resin canals; radial wall bordered pitting variable, uniseriate and bi-seriate, partially angular where bi-seriate and contacting, also circular to oblate within uniseriate chains; resinous tracheids particularly associated with growth interruptions; intercellular spaces are of small diameter but common among tracheids.

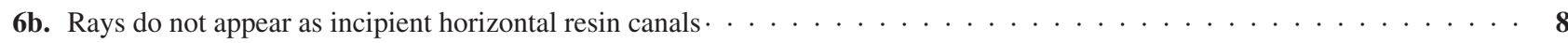

7a. In radial section, bordered pits uniseriate only $\ldots \ldots \ldots \ldots \ldots$

7b. In radial section, bordered pits uni- and bi-seriate $\ldots \ldots \ldots \ldots$

8a. Bi-seriate ray cells in tangential section in alternate rather than opposite arrangement Silicisilvaxylon secundacrystallus Moderately spaced thin-walled homocellular uniseriate and partially bi-seriate rays; where bi-seriate, ray cells alternately rather than oppositely placed; in some uniseriate rays individual cells separated by an intervening gap $\sim 10 \mu \mathrm{m}$; radial wall bordered pits when uniseriate are rounded and well-separated, when bi-seriate they alternate and are rounded and separated or are oblate; tangential wall bordered pits in very short chains and invariably uniseriate; intercellular spaces between tracheids common, either small or large; lacks the incipient resin canals, resinous tracheids and oppositely arranged bi-seriate pitting found in Silicisilvaxylon imprimicrystallus.

8b. Conspicuously bulging ray cells in radial section

Ginkgoxylpropinquus hewardii Frequent short to medium-height thin-walled homocellular less than well organized rays; ray cells in radial section conspicuously bulging (potato-tuber shaped); radial wall bordered pits mostly uniseriate and separated by weak crassulae, sometimes bi-seriate then circular and arranged alternately or oppositely; in cross section, poorly organized radial files and large diameter rounded elements among the tracheids.

8c. Heterocellular rays and axial parenchyma common

Protocupressinoxylon arizonica Short mostly homocellular sometimes heterocellular rays; radial wall bordered pits mostly uniseriate, infrequently bi-seriate then circular or angular and arranged alternately; in cross section, well organized radial files within definite growth rings; scattered axial parenchyma common

9a. Relatively large cupressoid pores in tangential walls

Pullisilvaxylon arizonicum Short homocellular, thin-walled, uniseriate rays; radial wall bordered pits mostly contacting and oblate exclusively uniseriate in long chains; in cross section, tracheids thick-walled generally rounded with large intercellular spaces; in tangential walls, small-diameter cupressoid pores.

9b. Relatively small taxodioid pores in tangential walls

Pullisilvaxylon daughertii Medium-height homocellular thin-walled frequent uniseriate rays; radial wall bordered pits mostly non-contacting and circular exclusively uniseriate in medium-length chains; in cross section, tracheids thin- to moderately thick-walled generally angular with small to inconspicuous intercellular spaces; in tangential walls, small-diameter taxodioid pores.

10a. In cross section, tracheids appear semi-circular

Arboramosa semicircumtrachea Short homocellular thin-walled widely spaced uniseriate rays; bordered pits equi-diameter circular or angular on all wall surfaces of the generally rounded tracheids; in cross section, tracheids generally thick-walled circular and semi-circular; infrequent axial parenchyma.

10b.In cross section, canals rather than half-bordered pits traverse tracheid walls to ray cells Crystalloxylon imprimacrystallus A mixture of short to long uniseriate homocellular thin-walled rays comprising small diameter thin-walled very well organized elliptical cells; radial wall bordered pits dominantly and abundantly bi-seriate, also uni- and tri-seriate, barely contacting rounded or oblate in outline, alternately arranged where bi-seriate, circular to oblate within short uniseriate chains; in cross section, large diameter thick-walled tracheids mostly rounded with large intercellular spaces, those adjoining a ray cell often appearing deformed ('squashed') with radial diameter $>5 \mathrm{x}$ tangential diameter; canals rather than pits traverse tracheid secondary walls to oculipores in ray cells.

10c. Tracheid radial files abruptly double, then revert in the following tier to a single radial file

Chinleoxylon knowltonii Short to medium-length homocellular thin-walled rays; radial wall bordered pits commonly bi-seriate also uniseriate in short chains of oblate or circular pits, when bi-seriate alternating and mostly circular but sometimes hexagonal; tangential wall uniseriate bordered pits also abundant; in cross section, mostly angular tracheids with medium thickness walls and without intercellular spaces, radial files abruptly double then revert in the next tier to a single radial file. 